\title{
Capital Regulation in a Macroeconomic Model with Three Layers of Default*
}

\author{
Laurent Clerc, ${ }^{\mathrm{a}}$ Alexis Derviz, ${ }^{\mathrm{b}}$ Caterina Mendicino, ${ }^{\mathrm{c}}$ \\ Stephane Moyen, ${ }^{\mathrm{d}}$ Kalin Nikolov, ${ }^{\mathrm{e}}$ Livio Stracca, ${ }^{\mathrm{f}}$ \\ Javier Suarez, ${ }^{\mathrm{g}}$ and Alexandros P. Vardoulakis ${ }^{\mathrm{h}}$ \\ ${ }^{a}$ Banque de France \\ ${ }^{\mathrm{b}}$ Czech National Bank \\ ${ }^{c}$ Banco de Portugal and UECE \\ ${ }^{\mathrm{d}}$ Deutsche Bundesbank \\ eEuropean Central Bank-DG Research \\ ${ }^{\mathrm{f}}$ European Central Bank-DG International \\ ${ }^{g}$ CEMFI and CEPR \\ ${ }^{\mathrm{h}}$ Board of Governors of the Federal Reserve System
}

We develop a dynamic general equilibrium model for the positive and normative analysis of macroprudential policies. Optimizing financial intermediaries allocate their scarce net worth together with funds raised from saving households across two lending activities, mortgage and corporate lending. For all borrowers (households, firms, and banks), external financing takes the form of debt which is subject to default risk.

${ }^{*}$ The project was developed as part of the ESCB Macro-prudential Research Network (MaRs). We are grateful for the feedback received from participants at the EABCN conference in Cambridge, the Second and the Final Conference of MaRs, the spring 2014 WGEM meeting, ESSIM 2014, the 2014 IJCB Conference, and at seminars at the Czech National Bank, Deutsche Bundesbank, Bank of Cyprus, Bank of England, Bank of Greece, Banco de Portugal, Banka Slovenije, International Monetary Fund, Norges Bank, Polish National Bank, Sveriges Riksbank, and University of Cologne. We also thank Michal Brzoza-Brzezina, Andrea Gerali, Philipp Hartmann, Donghun Joo, Nobu Kiyotaki, Michael Kumhof, Galo Nuño, Skander Van den Heuvel, and Rafael Wouters for valuable comments and suggestions and Dominik Supera for superb research assistance. The opinions expressed in this paper belong to the authors and do not necessarily reflect the views of the Eurosystem or the Federal Reserve System. Corresponding author: Javier Suarez, CEMFI, Casado del Alisal 5, 28014 Madrid, Spain. E-mail: suarez@cemfi.es. 
This "3D model" shows the interplay between three interconnected net worth channels that cause financial amplification and the distortions due to deposit insurance. We apply it to the analysis of capital regulation.

JEL Codes: E3, E44, G01, G21.

\section{Introduction}

The recent financial crisis has clearly illustrated that prudential regulation uniquely based on the soundness of individual institutions is not sufficient to ensure financial stability. As a consequence, macroprudential policy has been proposed to factor in the macroeconomic perspective and take into account the connections between the financial and the non-financial sectors, and the central role of financial intermediaries. Such policy should therefore be designed to address the contribution of financial stability, systemic risk, and the procyclicality of the financial system to overall economic performance. Beyond incorporating financial frictions and distortions, a good model for policy analysis in this area should put the banking system, and financial intermediation more generally, at the center of the stage.

The purpose of this paper is to encompass the most relevant aspects of macroprudential concern in a single model with enough microfoundations to allow us to perform a welfare analysis of macroprudential policy 11 The model presented in this paper is built with an eclectic perspective, trying to provide a synthesis of the most relevant interlinkages between the real and the financial sectors

\footnotetext{
${ }^{1}$ As further discussed in the literature review section, a number of recent papers have focused on introducing bank frictions into otherwise mainstream macroeconomic models. Some of these papers (e.g., Meh and Moran 2010, Gertler and Kiyotaki 2011) describe a bank net worth channel that operates essentially along the same lines as the conventional entrepreneurial net worth channel (notably in Kiyotaki and Moore 1997 and Bernanke, Gertler, and Gilchrist 1999) but causing fluctuations in the availability of bank credit rather than directly in entrepreneurial investment. Most papers either focus on one main bank friction (like the bank net worth channel) or otherwise capture several frictions in a reduced-form manner, without explicitly modeling the optimizing behavior of financial intermediaries and without explicitly addressing the welfare analysis of macroprudential policies.
} 
identified in the literature 2 This paper focuses on bank capital regulation, the key microprudential policy tool and arguably one of the main tools for macroprudential policy as well. Yet, we think of the model presented here as a first version of a framework that could be adapted to analyze other candidate macroprudential instruments, such as loan-to-value ratios, or extended so as to incorporate, for example, nominal rigidities and monetary policy.

The second main goal of the paper is to provide a model where default plays a central and material role. Up to the global financial crisis, the role of default has been largely overlooked in macroeconomics 3 A number of papers, following Kiyotaki and Moore (1997), allow for the possibility of default but rule it out in equilibrium through appropriately chosen financial contracts. Other papers, using the costly state verification (CSV) setup popularized by Bernanke, Gertler, and Gilchrist (1999) (henceforth BGG), allow for equilibrium default and the deadweight losses associated with it, although most of them consider state-contingent debt that prevents default to unexpectedly fluctuate in response to aggregate shocks. Therefore, both approaches abstract from some of the consequences of default for financial stability and for the real economy. In our work, default and its costs impinge on the balance sheet of the lenders, influencing their optimal behavior and thereby macroeconomic outcomes.

Our model belongs to the class of dynamic stochastic general equilibrium (DSGE) models, but the emphasis on financial intermediation and default sets it apart from the typical business-cycle model. By the same token, our construction is far away from the classical framework of microprudential supervision, which was very limited in its analysis of the impact of macroeconomic performance on financial intermediation and lacked the mission and the analytical tools to properly consider the impact of prudential policies on the real economy. Hence, we try to bridge the gap between the micro and macro literatures, and to build a framework which allows for the welfare analysis of the relevant policy instruments.

\footnotetext{
${ }^{2}$ See the report of the MaRs research network for a survey. See http://www. ecb.europa.eu/home/html/researcher_mars.en.html.

${ }^{3}$ For a discussion on the importance of introducing default in macro models, see Geanakoplos (2011) and Goodhart, Tsomocos, and Shubik (2013).
} 
More in detail, the model developed in this paper assumes banks intermediate funds from savers to final borrowers, and tries to coherently put together the following ingredients: (i) household bank deposits and loans for housing purchase, (ii) corporate-sector bank borrowing to fund capital accumulation, (iii) default risk in all classes of borrowing, including bank deposits, (iv) a net worth channel operating at the level of each levered sector, and (v) a bank funding fragility channel which operates through a premium demanded by depositors who suffer deadweight losses if banks default.

The rationale for macroprudential policies in our model arises from two key distortions associated with banks' external debt financing. Both of these encourage banks to become overleveraged and to expose themselves to too much failure risk.

The first distortion stems from banks' limited liability and the existence of deposit insurance 4 As in Kareken and Wallace (1978), deposit insurance pushes banks to take on risk at the expense of the deposit insurance agency (DIA), which may result in cheaper and more abundant bank lending than what a social planner would find optimal when internalizing the full costs of bank default (limited liability distortion).

The second distortion arises due to our assumption that depositors suffer some transaction costs in the event of a bank failure despite the presence of deposit insurance 5 In equilibrium, this leads to a deposit risk premium which raises banks' funding costs when failure risk is high. Moreover, we assume that, due to banks' opaqueness, this risk premium is related to economy-wide bank default risk rather than the individual risk of the issuing bank. This creates an incentive for banks to take excessive risk because their funding costs

\footnotetext{
${ }^{4}$ The most frequent justification for deposit insurance in the banking literature comes from the demandability of bank deposits and the attempt to prevent bank runs (Diamond and Dybvig 1983), issues from which our model fully abstracts. An alternative explanation, closer to our CSV framework, is provided by Dewatripont and Tirole (1994), who interpret bank supervision and deposit insurance as part of a social contract whereby small and unsophisticated savers delegate to bank authorities the disciplining role that creditors typically exert on their borrowers. Authorities, in exchange, offer deposit insurance to the savers as a means to reinforce their commitment to the supervisory task.

${ }^{5}$ This can be seen as a shortcut for explicitly modeling the fact that some bank liabilities (e.g., wholesale funding) are uninsured and investors demand a default risk premium in order to hold them.
} 
depend on system-wide choices rather than their own (bank funding cost externality).

Bank default is at the heart of both of the above distortions. Bank capital requirements make financial institutions safer and curtail their incentives to lever up excessively and lend too much. However, imposing limits on bank leverage is not without its costs. Our use of the CSV framework implies that credit may be too low from a social perspective (CSV distortion). Since CSV and the bank-related frictions discussed above distort credit in opposite directions, it is not clear a priori whether the social planner would like to impose high or low capital requirements. In fact, the steady-state welfare of households in our model is a hump-shaped function of credit availability as determined by bank capital regulation 6

We use the model to analyze the effects of capital requirements on the steady-state allocations and welfare and on the transmission of various types of shocks. On top of time-invariant capital requirements, possibly differentiated across classes of loans according to their risk, we also consider countercyclical adjustments to the capital ratios (adjustments that, in practice, might be implemented through the introduction of a countercyclical capital buffer, as in Basel III).

Three main results stand out in our analysis. First, in the context of our model, there is generally an optimal level of capital requirements. In effect, capital requirements reduce bank leverage, bank failure risk, and the implicit subsidies associated with deposit insurance. Simultaneously, they force the banks to make a greater use of bankers' limited wealth. This second aspect makes capital requirements have a potential impact on the cost of equity funding (due to its scarcity in the short run) and on the pattern of accumulation of wealth by bankers (in the medium to long run). Lower leverage and, in the short run, a larger cost of equity funding lead banks to extend less credit and to be less fragile. However, too-high levels of capital requirements may unduly restrict credit availability.

Second, we find that when bank leverage is high (because capital requirements are low), the economy is more responsive to shocks. Banks are more vulnerable not only to idiosyncratic shocks to their own performance but also to aggregate shocks, so their capacity

\footnotetext{
${ }^{6}$ This hump-shaped welfare function is conceptually similar to Benigno et al. (2013). However, their model is substantially different from ours.
} 
to supply credit to the economy is more volatile. Simultaneously, their borrowers are also more levered and more fragile due to the fact that their own steady-state leverage is higher because of the subsidies implied by the limited liability distortion. The result is a powerful channel of financial amplification.

Third, the countercyclical adjustment of capital ratios may significantly improve the benefits of high capital requirements, but once again only up to a certain level. Otherwise, the effects due to the increase in bank fragility following negative shocks will backfire. This is, in fact, what happens when the reference capital requirements are ex ante too low. On the one hand, a countercyclical reduction in the requirements may on impact allow the bank to charge lower loan rates on a larger amount of loans. On the other hand, if bank fragility gets further deteriorated, banks' funding costs will increase and their net worth will register further losses. These negative effects may well offset the intended impact of the countercyclical adjustment, causing long-lasting detrimental effects on credit supply and GDP.

The rest of the paper is organized as follows. In section 2 , we discuss how the paper fits into the existing literature. In section 3 we introduce the key elements of the core model, describing the equilibrium equations that directly emanate from agents' optimization. In section 4 , we complete the set of equilibrium equations with those that refer to market clearing, the funding of the DIA, and the description of the regulatory tools. Section 5 describes the calibration of the model. Section 6 contains the main positive and normative results. Section 7 concludes.

\section{Relation to Previous Literature}

Our model builds on a large literature which includes financial frictions in general equilibrium models, including among others Carlstrom and Fuerst (1997), Kiyotaki and Moore (1997), and BGG. Financial frictions are typically found to increase the persistence of shocks and to amplify their impact, though this is not necessarily the case in all models.7

\footnotetext{
${ }^{7}$ See Brunnermeier, Eisenbach, and Sannikov (2012) for a survey of the literature.
} 
We model the frictions affecting the relationship between borrowers and their financiers using the CSV framework of Townsend (1979) and Gale and Hellwig (1985) because it provides a rationale for the use of debt financing and for the deadweight losses associated with bankruptcy. As established by Williamson (1987) and Krasa and Villamil (1992), CSV can also be used to justify the existence of intermediaries who, by acting as delegated monitors à la Diamond (1984), economize on the potential duplication of verification costs when funding a borrower requires the funds of several savers.

Our model is thus related to that of BGG, who integrate the CSV approach into a macroeconomic setup 8 We depart, though, from BGG and most of the subsequent literature in assuming that debt is non-contingent, which, realistically, makes our banks exposed to rises in loan default rates caused by aggregate shocks 9

We model the evolution of bank net worth along the same lines as in a number of recent papers (Gertler and Kiyotaki 2010; Gertler and Karadi 2011; Gertler, Kiyotaki, and Queralto 2012), which have also emphasized the presence of financing constraints for banks as a key factor in the propagation of shocks. In these papers, banks' financing constraints arise from the fact that bankers can divert a fraction of the funds under their management. In our work, the limit on banks' leverage comes from regulatory capital requirements that are put in place to reduce the over-investment (or excessive risk taking) caused by limited liability and deposit insurance (Kareken and Wallace 1978) 10 In addition, to keep track of the transmission of default risk and net worth losses across sectors, we model explicitly

\footnotetext{
${ }^{8}$ In a comparison of the properties of models that have collateral constraints like in Kiyotaki and Moore (1997) with models that have an external finance premium as in BGG, Brzoza-Brzezina, Kolasa, and Makarski (2013) conclude that the business-cycle properties of the latter are more in line with the empirical evidence.

${ }^{9}$ Our emphasis on default is similar to several models that have analyzed macroprudential issues outside the DSGE tradition, such as Goodhart, Sunirand, and Tsomocos (2006) and Goodhart et al. (2012), who study how combinations of macroprudential tools (including capital requirements) can address default and fire-sale externalities in a model where traditional and shadow banking sectors interact. Another example is Repullo and Suarez (2013), who assess capital requirements in the presence of a trade-off between causing credit crunch effects in recessions and reducing the social cost of bank failures.

${ }^{10}$ This view has a long tradition in the banking literature (see Bhattacharya, Boot, and Thakor 1998 for a survey). Van den Heuvel (2008) analyzes bank capital regulation in a macroeconomic model without aggregate shocks in which
} 
the intermediation chain that links saving households with household and corporate borrowers.

Our work is connected with several recent attempts to incorporate banking in otherwise standard DSGE models; these include Goodfriend and McCallum (2007), Curdia and Woodford (2008), Gerali et al. (2010), Meh and Moran (2010), and Christiano, Motto, and Rostagno (2014). As in our paper, this literature mostly focuses on direct lending by banks, excluding securitization and investment banking activities. In most of this work the emphasis is on the role of bank lending in the propagation of shocks (typically monetary policy shocks) or in the optimal conduct of monetary policy, rather than on the rationale for macroprudential policies. Moreover, default normally does not feature prominently or at all. An exception is Angeloni and Faia (2013), who focus on capital regulation in a model where banks are fragile and subject to runs, and the main distortion arises from the fact that the projects funded by banks may be subject to costly early liquidation if banks get in trouble 11

Hirakata, Sudo, and Ueda (2013) also consider the full intermediation chain and allow for borrowers' and banks' default, but they consider uninsured deposits, while in our analysis the effect of deposit insurance on banks' risk taking is one of the reasons for the need for macroprudential policy. This is also the case in Martinez-Miera and Suarez (2012), who analyze the effect of capital requirements on banks' incentive to extend loans with highly correlated defaults in case a so-called systemic shock occurs. Collard et al. (2012) look at the interplay between prudential and monetary policy instruments in a related model where deposit insurance can also lead to socially excessive risk taking by banks.

Brunnermeier and Sannikov (2014) use a continuous-time methodology to solve for the full dynamics of a stylized macroeconomic model where some experts' wealth determines their ability to finance productive investment, and where the interaction with asset

deposits offer liquidity services to households and bank leverage induces banks to get involved in risk shifting.

${ }^{11}$ Benes and Kumhof (2011) also analyze capital requirements in a dynamic model where, like in ours, banks finance their borrowers with non-contingent debt. However, their model adopts several other unconventional assumptions (e.g., on the monetary nature of credit extension) that make it hard to compare with the rest of the literature. 
price volatility gives rise to highly non-linear dynamics. Although the paper does not discuss macroprudential policies, its results suggest that non-linearities might be important in a model like ours. Assessing this, however, is a challenge left for future research since we currently solve the model with standard perturbation methods which neglect potential non-linear effects 12

Finally, our paper shares the goal of finding a rationale for macroprudential policies with papers that have recently put the emphasis on pecuniary externalities, including Bianchi and Mendoza (2010), Jeanne and Korinek (2010), Bianchi (2011), Gersbach and Rochet (2012), and Christiano and Ikeda (2013). In our model the endogenous leverage of households and firms is also affected by asset prices, so pecuniary externalities might also be present, although we do not explicitly assess their contribution to distorting the allocation of credit in our economy.

\section{Model Setup}

We consider an economy populated by households, entrepreneurs, and bankers, whose main characteristics are as follows:

Households. Households are risk averse and infinitely lived and derive utility from a consumption good and from a durable good, housing, which provides housing services to its owners. The consumption good acts as the numeraire. Similar to Iacoviello (2005) and subsequent literature, there are two types of households that differ in their discount factor, patient and impatient. Each type is grouped in a distinct representative dynasty which provides risk sharing to its members. In equilibrium, patient households are savers who buy houses outright, while the impatient households borrow from banks, using their holdings of housing as collateral. Mortgage debt is provided to the individual members of the dynasty against their individual housing units on a limited liability non-recourse basis. This implies the possibility of defaulting on mortgage debt at an individual level with the only implication for the borrower of losing the housing good on which the mortgage is secured. Thus,

\footnotetext{
${ }^{12} \mathrm{~A}$ related challenge is the analysis of optimal capital requirements from the perspective of stochastic welfare rather than, as we do in this paper, from the perspective of the welfare attained in the non-stochastic steady state.
} 
in contrast to Iacoviello (2005), mortgage loans feature default risk and, in case of default, the repossession of collateral by the banks involves verification costs similar to those considered in BGG. Both types of households supply labor in a competitive market.

Entrepreneurs. Entrepreneurs are risk-neutral agents specialized in owning and maintaining the stock of physical capital, which they rent in each period to the firms involved in the production of the consumption good 13 They live across two consecutive periods and derive utility from donating a part of their final wealth to the saving dynasty (in what can be interpreted as "paying dividends") and from leaving another part as a bequest to the next generation of entrepreneurs (in what can be interpreted as "retaining earnings"). This overlapping-generations formulation, which will also be postulated for the bankers, gives us the same sort of dynamics for entrepreneurial and banking net worth as in BGG. Simultaneously, it allows us to reduce the number of classes of agents to care about in the welfare calculations. Specifically, it allows us to focus on a weighted sum of the intertemporal expected utility of the patient and the impatient households without neglecting any of the consumption capacity generated in the economy. Entrepreneurs finance their initial purchases of physical capital partly with the inherited net worth and partly with corporate loans provided by banks. Similar to household loans, corporate loans are subject to limited liability and default risk, and recovering residual returns from bankrupt entrepreneurs leads banks to incur verification costs.

Bankers. Bankers are the providers of inside equity to perfectly competitive financial intermediaries that we call banks. Like entrepreneurs, bankers are risk-neutral agents who live across two consecutive periods and derive utility from making transfers to the saving dynasty and leaving bequests to the next cohort of bankers 14 At the end of each period, the gross return on bank equity is fully distributed to the bankers, who in turn distribute it to the patient households ("dividends") and to the next cohort of bankers ("retained earnings").

\footnotetext{
${ }^{13}$ A possible interpretation is that physical capital would suffer prohibitively high depreciation rates if owned and maintained by any other class of agents.

${ }^{14}$ The induced dynamics of bankers' net worth is similar to that in Gertler and Karadi (2011), where a fraction of households become bankers at random in every period and remain bankers in subsequent periods with some probability.
} 
To complete the model overview, we need to refer to banks, consumption-good-producing firms, and capital-good-producing firms:

Banks. Banks' outside funding is made up of fully insured deposits raised among the saving households. Banks operate under limited liability and may default due to both idiosyncratic and aggregate shocks to the performance of their loan portfolios. Deposit insurance is funded within each period by levying lump-sum taxes on patient households, if needed. From the standpoint of savers, however, we assume that recovering the fully insured principal and interest of their deposits in the case of bank failure is costly in terms of time and effort, so that deposits may still pay a risk premium that depends on the average bank's default risk. This captures the notion that depositors are unable to properly monitor their banks and deposit risk premia depend on the general health of the banking system. Bankers' inside equity contributions are necessary for the banks to comply with the prevailing regulatory capital requirement.

Production of the Consumption Good. There is a perfectly competitive consumption-good-producing sector made up of firms owned by the patient households. These firms combine capital rented from entrepreneurs with household and entrepreneurial labor inputs in order to produce the consumption good. This sector is not directly affected by financial frictions.

Production of the Capital Good and Housing. Finally, there are two perfectly competitive sectors made up of firms which produce new units of the capital good and of housing, respectively. Like in Gertler, Kiyotaki, and Queralto (2012), these firms, owned by patient households, face investment adjustment costs and optimize intertemporally in response to changes in the price of capital. As with the consumption-good-producing sector, these sectors are not directly affected by financial frictions.

We now turn to describe all the ingredients in detail.

\subsection{Households}

The economy is populated by two representative dynasties made up of a measure-one continuum of ex ante identical households each. Households are risk averse and maximize some time-separable expected utility functions. One dynasty, identified by the superscript $s$, is made of relatively patient households with a discount factor 
$\beta^{s}$. The other dynasty, identified by the superscript $m$, is made of more impatient households with a discount factor $\beta^{m} \leq \beta^{s}$. Thus, in equilibrium, the patient households save and the impatient households borrow. Dynasties provide consumption risk sharing to their members and are in charge of making most household decisions 15

\subsubsection{Saving Households}

The dynasty of patient households maximizes

$$
E_{t}\left[\sum_{i=0}^{\infty}\left(\beta^{s}\right)^{t+i}\left[\log \left(c_{t+i}^{s}\right)+v^{s} \log \left(h_{t+i-1}^{s}\right)-\frac{\varphi^{s}}{1+\eta}\left(l_{t+i}^{s}\right)^{1+\eta}\right]\right],
$$

where $c_{t}^{s}$ denotes the consumption of non-durable goods and $h_{t-1}^{s}$ denotes the total stock of housing held by the various members of the dynasty; $l_{t}^{s}$ denotes hours worked in the consumption-goodproducing sector, with $\eta$ the inverse of the Frisch elasticity of labor supply; $v^{s}$ and $\varphi^{s}$ are preference parameters 16

The patient households' dynamic budget constraints read as follows:

$$
c_{t}^{s}+q_{t}^{H} h_{t}^{s}+d_{t} \leq w_{t} l_{t}^{s}+q_{t}^{H}\left(1-\delta_{t}^{H}\right) h_{t-1}^{s}+\widetilde{R}_{t}^{D} d_{t-1}-T_{t}+\Pi_{t}^{s},
$$

where $q_{t}^{H}$ is the price of housing, $\delta_{t}^{H}$ is the (possibly time-varying) rate at which housing units depreciate, $w_{t}$ is the wage rate, and

$$
\widetilde{R}_{t}^{D}=R_{t-1}^{D}\left(1-\gamma P D_{t}^{b}\right),
$$

where $R_{t}^{D}$ is the fixed (gross) interest rate received at $t$ on the savings deposited at banks at $t-1$ in the previous period and $P D_{t}^{b}$ stands for the fraction of deposits in banks that fail in period $t$, which computed as the average deposit-weighted bank default rate realized in period $t$ (further specified in equation (38) below). The principal and

\footnotetext{
${ }^{15}$ This latter feature is convenient for the solution of the model with standard techniques (i.e., avoiding kinks).

${ }^{16}$ For the sake of simplicity, the analysis presented in this paper only refers to a limited set of shocks. However, it is possible to allow the preference parameters to vary over time (potentially causing fluctuations in, e.g., the equilibrium price of housing) in response to exogenous shocks.
} 
interest of bank deposits are fully guaranteed by a deposit insurance agency (DIA) that, for simplicity, is assumed to ex post balance its budget by imposing a lump-sum tax $T_{t}$ on patient households. However, we assume that in the case of bank failure, households incur a linear transaction cost $\gamma$ whenever they have to recover their funds 17 This transaction cost introduces a link between the bank probability of default and bank funding costs and a wedge between the rate of return on deposits and the risk-free rate, while preserving the usual distortions associated with limited liability and deposit insurance 18 Finally, $\Pi_{t}^{s}$ includes the profits accruing to the saving households from the ownership of the capital-good- and housing-producing firms as well as the donations ("dividend payments") received from entrepreneurs and bankers.

The housing depreciation rate is time varying and follows an $\mathrm{AR}(1)$ process:

$$
\delta_{t}^{H}=\left(1-\rho^{\delta^{H}}\right) \delta^{H}+\rho^{\delta^{H}} \delta_{t-1}^{H}+\varepsilon_{t}^{\delta^{H}},
$$

where $\delta^{H}$ is the steady-state depreciation rate, $\rho^{\delta^{H}}$ is the persistency parameter, and $\varepsilon_{t}^{\delta^{H}}$ is an i.i.d. shock with variance $\sigma_{\delta^{H}}^{2}$.

\subsubsection{Borrowing Households}

The objective function of the representative dynasty of impatient households has the same form and parameters as (1), except for the discount factor, which for them is $\beta^{m}<\beta^{s}$ and will induce the members of this dynasty to borrow rather than save in equilibrium. This explains the differences in their dynamic budget constraint, which read as follows:

$$
\begin{aligned}
c_{t}^{m}+q_{t}^{H} h_{t}^{m}-b_{t}^{m} \leq & w_{t} l_{t}^{m}+\int_{0}^{\infty} \max \left\{\omega_{t}^{m} q_{t}^{H}\left(1-\delta_{t}^{H}\right) h_{t-1}^{m}\right. \\
& \left.-R_{t-1}^{m} b_{t-1}^{m}, 0\right\} d F^{m}\left(\omega_{t}^{m}\right)
\end{aligned}
$$

\footnotetext{
${ }^{17}$ For evidence that bank failure is costly to depositors even in the presence of deposit insurance, see Brown, Guin, and Morkoetter (2013).

${ }^{18}$ Notice that we assume that depositors cannot attach subjective estimates of the probability of failure to each bank. This is consistent with the view in Dewatripont and Tirole (1994) that depositors lack the capacity to discipline the banks. Hence individual banks preserve their incentives to possibly take excessive risks (in the form of high leverage and cheap lending) at the expense of the DIA.
} 
where $b_{t}^{m}$ is the dynasty's aggregate borrowing from the banking system and $R_{t-1}^{m}$ is the contractual gross interest rate on the housing loan of size $b_{t-1}^{m}$ agreed upon with a bank in the previous period. The term in the integral reflects the fact that the housing good and the debt secured against it are assumed to be distributed across the individual households that constitute the dynasty. Each impatient household experiences at the beginning of each period $t$ an idiosyncratic shock $\omega_{t}^{m}$ to the efficiency units of housing owned from the previous period and has the option to (strategically) default on the non-recourse housing loans associated with those units 19

The shock $\omega_{t}^{m}$ is assumed to be independently and identically distributed across the impatient households, and to follow a lognormal distribution with density and cumulative distributions functions denoted by $f^{m}(\cdot)$ and $F^{m}(\cdot)$, respectively. This shock makes the effective resale value of the housing units acquired in the previous period $\tilde{q}_{t}^{H}=\omega^{m} q_{t}^{H}\left(1-\delta_{t}^{H}\right)$ and, given that default is costless for households, makes default on the underlying loan ex post optimal for the household whenever $\omega_{t}^{m} q_{t}^{H}\left(1-\delta_{t}^{H}\right) h_{t-1}^{m}<R_{t-1}^{m} b_{t-1}^{m} 20$ This explains the presence of the max operator in the integral in (4).

Housing Loans. After the realization of the idiosyncratic shock $\omega_{t}^{m}$, each individual household decides whether to default on the individual loans attached to the housing held from the previous period and the residual net worth is passed on to the dynasty, which is not liable for any unpaid debt. The dynasty then makes the decisions on consumption, housing, labor supply, and debt for period $t$ and allocates them evenly across its members.

Fluctuations in the net worth of the dynasty (as captured by the last term in the right-hand side of (4)) are driven by the changes in the net worth of the loan-repaying households as well as the realization of zero net worth from all housing units owned by members that default on their housing loans. Default in period $t$ occurs for

\footnotetext{
${ }^{19}$ This shock is intended to capture idiosyncratic fluctuations in the value of houses and can be interpreted as a reduced-form representation of a sudden improvement or worsening in the neighborhood, in the social equipment available nearby, or in the resource cost of maintaining the property. See also Forlati and Lambertini (2011), who use a similar formulation.

${ }^{20}$ See Geanakoplos (2003) for a discussion of the ex post optimality of this type of behavior by the borrower, and Goodhart et al. (2012) for an extension to the analysis of mortgage contracts backed by housing collateral.
} 


$$
\omega_{t}^{m} \leq \bar{\omega}_{t}^{m}=\frac{x_{t-1}^{m}}{R_{t}^{H}}
$$

where

$$
R_{t}^{H} \equiv \frac{q_{t}^{H}\left(1-\delta_{t}^{H}\right)}{q_{t-1}^{H}}
$$

is the ex post average realized gross return on housing, and

$$
x_{t}^{m} \equiv \frac{R_{t}^{m} b_{t}^{m}}{q_{t}^{H} h_{t}^{m}}
$$

is a measure of a household leverage. The fraction of defaulted mortgages at period $t$ can then be expressed as $F^{m}\left(\bar{\omega}_{t}^{m}\right)$ and the net worth accruing to the dynasty out of its aggregate housing investment in the previous period can be written as

$$
\Phi_{t}^{m} \equiv\left(\int_{\bar{\omega}_{t}^{m}}^{\infty}\left(\omega_{t}^{m}-\bar{\omega}_{t}^{m}\right) d F\left(\omega_{t}^{m}\right)\right) R_{t}^{H} q_{t-1}^{H} h_{t-1}^{m} .
$$

Now, using the same intermediate notation as in BGG, we can more compactly write

$$
\Phi_{t}^{m}=\left(1-\Gamma^{m}\left(\bar{\omega}_{t}^{m}\right)\right) R_{t}^{H} q_{t-1}^{H} h_{t-1}^{m},
$$

where

$$
\Gamma^{m}\left(\bar{\omega}_{t}^{m}\right)=\int_{0}^{\bar{\omega}_{t}^{m}} \omega_{t}^{m} f\left(\omega_{t}^{m}\right) d \omega_{t}^{m}+\bar{\omega}_{t}^{m} \int_{\bar{\omega}_{t}^{m}}^{\infty} f\left(\omega_{t}^{m}\right) d \omega_{t}^{m} .
$$

The variable $\Phi_{t}^{m}$ can be interpreted as net housing equity after accounting for repossessions of defaulting households.

Since each of the borrowing households default on the loans taken at period $t$ according to a similar pattern of behavior, the terms of such loans must satisfy the following participation constraint for the lending bank:

$E_{t}\left(1-\Gamma^{H}\left(\bar{\omega}_{t+1}^{H}\right)\right)\left(\Gamma^{m}\left(\bar{\omega}_{t+1}^{m}\right)-\mu^{m} G^{m}\left(\bar{\omega}_{t+1}^{m}\right)\right) R_{t+1}^{H} q_{t}^{H} h_{t}^{m} \geq \rho_{t} \phi_{t}^{H} b_{t}^{m}$. 
Intuitively, this constraint says that the bankers who contribute equity $\phi_{t}^{H} b_{t}^{m}$ to the lending bank (where $\phi_{t}^{H}$ is the capital requirement on housing loans) should expect a gross expected return on their contribution at least as high as some market-determined required rate of return $\rho_{t}$ which is exogenous for any individual bank although endogenous in the aggregate (as we explain later). Therefore, $\rho_{t} \phi_{t}^{H} b_{t}^{m}$ measures total gross equity returns for a given bank.

The expression in the left-hand side of the inequality accounts for the total equity returns associated with a portfolio of housing loans to the various members of the impatient dynasty. The term $\mu^{m} G\left(\bar{\omega}_{t+1}^{m}\right)$ reflects the proportional verification costs $\mu^{H}$ incurred in the repossession of the fraction $G^{m}\left(\bar{\omega}_{t+1}^{m}\right)$ of housing units which defaulting loans were borrowing against, where $G^{m}\left(\bar{\omega}_{t+1}^{m}\right)=\int_{0}^{\bar{\omega}_{t+1}^{m}} \omega_{t+1}^{m} f^{m}\left(\omega_{t+1}^{m}\right) d \omega_{t+1}^{m}$.

The factor $\left(1-\Gamma^{H}\left(\bar{\omega}_{t}^{H}\right)\right)$ plays a similar role to the factor $\left(1-\Gamma^{m}\left(\bar{\omega}_{t}^{m}\right)\right)$ in $(6)$ and accounts for bank leverage and the possibility that the individual bank that lends to households (the superscript $H$ identifies claims of banks of such class) fails due to sufficiently adverse idiosyncratic or aggregate shocks to the performance of its loans. The full description of the threshold $\bar{\omega}_{t}^{H}$ of the idiosyncratic shock below which the bank fails is provided in sub-section 3.4.

Note that limited liability and the fact that bank liabilities (deposits) are insured imply that a bank can meet the required return on equity with a lower lending rate than in their absence. This suggests that these distortions act in the direction of expanding credit availability for entrepreneurs and impatient households. It should also be emphasized that the probability of households' default on their loans (and, similarly, the probability that a bank of class $H$ defaults on its deposits) is affected by $R_{t}^{H}$, a variable that responds to aggregate shocks. Therefore, default in this model is a function of both idiosyncratic and aggregate shocks, unlike in BGG and most other papers in the literature, which exclude the influence of the latter by assuming that debt is state contingent 21

\footnotetext{
${ }^{21}$ Ruling out state-contingent debt implies a restriction in the contracting space. Loan and deposit contracts in our economy are incomplete in that they
} 
Borrowing Households' Optimization Problem. With all the prior ingredients, the decision problem of the borrowing households can be compactly written as a contracting problem between the corresponding representative dynasty and its bank:

$$
\begin{aligned}
& \max _{\left\{c_{t+i}^{m}, h_{t+i}^{m}, l_{t+i}^{m}, x_{t+i}^{m}, b_{t+i}^{m}\right\}_{i=0}^{\infty}} \\
& \times E_{t}\left[\sum_{i=0}^{\infty}\left(\beta^{m}\right)^{t+i}\left[\log \left(c_{t+i}^{m}\right)+v^{m} \log \left(h_{t+i}^{m}\right)-\frac{\varphi^{m}}{1+\eta}\left(l_{t+i}^{m}\right)^{1+\eta}\right]\right]
\end{aligned}
$$

subject to the budget constraint of the dynasty,

$$
c_{t}^{m}+q_{t}^{H} h_{t}^{m}-b_{t}^{m} \leq w_{t} l_{t}^{m}+\left(1-\Gamma^{m}\left(\frac{x_{t}^{m}}{R_{t+1}^{H}}\right)\right) R_{t+1}^{H} q_{t}^{H} h_{t}^{m},
$$

and the participation constraint of the bank,

$$
\begin{aligned}
E_{t} & {\left[\left(1-\Gamma^{H}\left(\bar{\omega}_{t+1}^{H}\right)\right)\left(\Gamma^{m}\left(\frac{x_{t}^{m}}{R_{t+1}^{H}}\right)-\mu^{m} G^{m}\left(\frac{x_{t}^{m}}{R_{t+1}^{H}}\right)\right) R_{t+1}^{H}\right] q_{t}^{H} h_{t}^{m} } \\
& =\rho_{t} \phi_{t}^{H} b_{t}^{m},
\end{aligned}
$$

which we impose with equality without loss of generality 22

\subsection{Entrepreneurs}

To guarantee easy aggregation and generate the same type of net worth dynamics as in Bernanke, Gertler, and Gilchrist (1999) but in a slightly more microfounded manner, we assume that entrepreneurs belong to a sequence of overlapping generations of two-period-lived risk-neutral agents. Each generation of entrepreneurs inherits wealth

cannot be made fully contingent on aggregate variables (perhaps due to verifiability problems, publication lags, potential manipulability if contractually relevant, etc.).

${ }^{22}$ In principle, the borrowing rate $R_{t}^{m}$ is part of the housing loan contract and, hence, can be treated as part of the decision variables of the impatient dynasty in period $t$. However, treating the intermediate variable $x_{t}^{m}$ as part of the contract variables (together with $b_{t}^{m}$ and $h_{t}^{m}$ ) allows us to write the entire contract problem without explicit reference to $R_{t}^{m}$. 
in the form of bequests $n_{t}^{e}$ from the previous generation of entrepreneurs. Entrepreneurs are the only agents who can own and maintain the capital stock. They purchase new capital from capital goods producers and depreciated capital from the previous generation of entrepreneurs, and then rent it to the contemporaneous producers of the consumption good. Entrepreneurs finance their capital holdings with their own initial net worth $n_{t}^{e}$ and with loans $b_{t}^{e}$ received from the banks specialized in corporate loans.

An entrepreneur born at time $t$ values the donations made to the patient dynasty at time $t+1$ ("dividends"), $c_{t+1}^{e}$, and the bequests left to the next cohort of entrepreneurs ("retained earnings"), $n_{t+1}^{e}$, according to the utility function $\left(c_{t+1}^{e}\right)^{\chi^{e}}\left(n_{t+1}^{e}\right)^{1-\chi^{e}}$, with $\chi^{e} \in(0,1) 23$ Thus, once in period $t+1$, the entrepreneur solves

$$
\max _{c_{t+1}^{e}, n_{t+1}^{e}}\left(c_{t+1}^{e}\right)^{\chi^{e}}\left(n_{t+1}^{e}\right)^{1-\chi^{e}}
$$

subject to

$$
c_{t+1}^{e}+n_{t+1}^{e} \leq W_{t+1}^{e} .
$$

Optimizing behavior then yields the "dividend payment" rule

$$
c_{t+1}^{e}=\chi^{e} W_{t+1}^{e}
$$

and the "earnings retention" rule

$$
n_{t+1}^{e}=\left(1-\chi^{e}\right) W_{t+1}^{e},
$$

and an indirect utility equal to $W_{t+1}^{e}$.

The decision problem of the entrepreneur who starts up at $t$ can then be written as

$$
\max _{k_{t}, b_{t}^{e}, R_{t}^{F}} E_{t}\left(W_{t+1}^{e}\right)
$$

${ }^{23}$ These preferences involve impure altruism in the form introduced by Andreoni (1989) and used, e.g., in Aghion and Bolton (1997): entrepreneurs directly enjoy the "warm glow" from giving, independently of the extent to which the recipients actually benefit from the donation. 
subject to the period $t$ resource constraint

$$
q_{t}^{K} k_{t}-b_{t}^{e}=n_{t}^{e}
$$

the definition

$$
W_{t+1}^{e}=\max \left[\omega_{t+1}^{e}\left(r_{t+1}^{k}+\left(1-\delta_{t+1}\right) q_{t+1}^{K}\right) k_{t}-R_{t}^{F} b_{t}^{e}, 0\right],
$$

and a bank participation constraint which will be fully specified in the next sub-section. In these expressions, $q_{t}^{K}$ is the price of capital at period $t, k_{t}$ is the capital held by the entrepreneur in period $t, b_{t}^{e}$ is the amount borrowed from the bank in period $t, \delta_{t}$ is the timevarying depreciation rate of each efficiency unit of capital, $r_{t}^{K}$ is the rental rate per efficiency unit of capital, and $R_{t}^{F}$ is the contractual gross interest rate of the loan taken from the bank in period $t$.

Note that the depreciation rate $\delta_{t}$ is time varying and, similarly to the housing depreciation, follows an AR(1) process:

$$
\delta_{t}=\left(1-\rho^{\delta}\right) \delta+\rho^{\delta} \delta_{t-1}+\varepsilon_{t}^{\delta}
$$

where $\delta$ is the steady-state depreciation rate, $\rho^{\delta}$ is the persistency parameter, and $\varepsilon_{t}^{\delta}$ is an i.i.d. shock with variance $\sigma_{\delta}^{2}$.

The factor $\omega_{t+1}^{e}$ that multiplies the return from capital holdings is an idiosyncratic shock to the entrepreneur's efficiency units of capital. This shock realizes after the period $t$ loan with the bank is agreed to and prior to renting the available capital to consumption good producers in that date. With a role similar to the shock $\omega_{t+1}^{m}$ suffered by the housing held by borrowing households, the shock $\omega_{t+1}^{e}$ is a simple way to rationalize the existence of idiosyncratic shocks to the entrepreneurs' performance and to generate a nontrivial default rate on entrepreneurial loans. The shock is independently and identically distributed across entrepreneurs and follows a log-normal distribution with an expected value of one, and density and cumulative distribution functions denoted $f^{e}(\cdot)$ and $F^{e}(\cdot)$, respectively.

Similar to all other borrowers in our economy, an entrepreneur cannot be held liable for any contracted repayments due to banks (which amount to $R_{t}^{F} b_{t}^{e}$ in period $t+1$ ) over and above the gross returns that she obtains on the capital investment undertaken in the previous period, $\left(r_{t+1}^{K}+\left(1-\delta_{t+1}\right) q_{t+1}^{K}\right) \omega_{t+1}^{e} k_{t}$. Accordingly, 
the max operator in (17) takes into account limited liability and the possibility that entrepreneurs default on their bank loans.

\subsubsection{Entrepreneurial Loans}

Let

$$
R_{t+1}^{K}=\frac{r_{t+1}^{K}+\left(1-\delta_{t+1}\right) q_{t+1}^{K}}{q_{t}^{K}}
$$

denote the gross return per efficiency unit of capital obtained in period $t+1$ out of capital owned in period $t$. Then the entrepreneur will repay her loan at $t+1$ whenever her idiosyncratic shock $\omega_{t+1}^{e}$ exceeds the following threshold:

$$
\bar{\omega}_{t+1}^{e} \equiv \frac{R_{t}^{F} b_{t}^{e}}{R_{t+1}^{K} q_{t}^{K} k_{t}} \equiv \frac{x_{t}^{e}}{R_{t+1}^{K}},
$$

where $x_{t}^{e} \equiv \frac{R_{t}^{F} b_{t}^{e}}{q_{t}^{K} k_{t}}$ denotes entrepreneurial leverage as measured by the ratio of contractual debt repayment obligations at $t+1, R_{t}^{F} b_{t}^{e}$, to the value of the capital purchased at $t, q_{t}^{K} k_{t}$. Notice that (18) implies (differently from BGG, where the contractual debt repayments are made contingent on $R_{t+1}^{K}$ ) that fluctuations in $R_{t+1}^{K}$ will (realistically) produce fluctuations in entrepreneurial default rates.

When an entrepreneur defaults on her loan, the bank only recovers a fraction $1-\mu^{e}$ of the gross return of the capital available to the defaulted entrepreneur, where $\mu^{e}$ stands for verification costs incurred by the bank when taking possession of the returns and selling the underlying capital to other entrepreneurs. Hence a bank recovers $R_{t}^{F} b_{t}^{e}$ from performing loans and $\left(1-\mu^{e}\right) R_{t+1}^{K} q_{t}^{K} \omega_{t+1}^{e} k_{t}$ from non-performing loans. Ex ante, lenders recognize that under certain realizations of the idiosyncratic and the aggregate shocks, entrepreneurs will go bankrupt, especially when their ex ante leverage $x_{t}^{e}$ is high.

The division between entrepreneurs and their bank of the total gross returns on a well-diversified portfolio of entrepreneurial investments at period $t$ can be compactly expressed using notation similar to the one already introduced for borrowing households: 


$$
\Gamma^{e}\left(\bar{\omega}_{t+1}^{e}\right)=\int_{0}^{\bar{\omega}_{t+1}^{e}} \omega_{t+1}^{e} f^{e}\left(\omega_{t+1}^{e}\right) d \omega_{t+1}^{e}+\bar{\omega}_{t+1}^{e} \int_{\bar{\omega}_{t+1}^{e}}^{\infty} f^{e}\left(\omega_{t+1}^{e}\right) d \omega_{t+1}^{e},
$$

which gives the share of the gross returns (gross of verification costs) that will accrue to the bank, and

$$
G^{e}\left(\bar{\omega}_{t+1}^{e}\right)=\int_{0}^{\bar{\omega}_{t+1}^{e}} \omega_{t+1}^{e} f^{e}\left(\omega_{t+1}^{e}\right) d \omega_{t+1}^{e},
$$

which denotes the part of those returns that comes from defaulted loans. Then the verification costs incurred by the bank on its portfolio of loans to entrepreneurs will be $\mu^{e} G^{e}\left(\omega_{t+1}^{e}\right)$, and the net share of the total gross returns of the portfolio that the bank appropriates can be expressed as $\Gamma^{e}\left(\bar{\omega}_{t+1}^{e}\right)-\mu^{e} G^{e}\left(\omega_{t+1}^{e}\right)$. We will use this expression below when introducing the bank's participation constraint into the entrepreneur's optimization problem.

\subsubsection{Entrepreneurs' Optimization Problem}

The contracting problem between the entrepreneur and her bank in period $t$ can be written as one of maximizing the entrepreneur's expected wealth at $t+1$,

$$
\max _{x_{t}^{e}, k_{t}} E_{t}\left[\left(1-\Gamma^{e}\left(\frac{x_{t}^{e}}{R_{t+1}^{K}}\right)\right) R_{t+1}^{K} q_{t}^{K} k_{t}\right],
$$

subject to the participation constraint of the bank:

$$
\begin{aligned}
& E_{t}\left[\left(1-\Gamma^{F}\left(\bar{\omega}_{t+1}^{F}\right)\right)\left(\Gamma^{e}\left(\frac{x_{t}^{e}}{R_{t+1}^{K}}\right)-\mu^{e} G^{e}\left(\frac{x_{t}^{e}}{R_{t+1}^{K}}\right)\right)\right] R_{t+1}^{K} q_{t}^{K} k_{t} \\
& \quad=\rho_{t} \phi_{t}^{F}\left(q_{t}^{K} k_{t}-n_{t}^{e}\right)
\end{aligned}
$$

which we can write with equality without loss of generality. Just like in the case of the bank extending loans to impatient households in (10), equation (21) states that the expected payoffs appropriated by the equityholders of a bank which holds a portfolio of loans to entrepreneurs must be sufficient to guarantee the expected rate of return $\rho_{t}$ that the bankers require on the wealth that they contribute to the 
bank. Bankers' equity contribution, $\phi_{t}^{F}\left(q_{t}^{K} k_{t}-n_{t}^{e}\right)$, is determined by the need to comply with a capital requirement $\phi_{t}^{F}$ on each unit of lending.

The factor $\left(1-\Gamma^{F}\left(\bar{\omega}_{t+1}^{F}\right)\right)$ that multiplies the left-hand side of (21) accounts for bank leverage and the possibility that an individual bank specializing in corporate loans (the superscript $F$ identifies such class of banks) fails due to sufficiently adverse idiosyncratic or aggregate shocks to the performance of its portfolio of entrepreneurial loans. The full details of the threshold $\bar{\omega}_{t+1}^{F}$ of the idiosyncratic shock below which the bank fails are presented below in sub-section 3.4.

The final wealth of the entrepreneurs that start up in period $t$ can be written as

$W_{t+1}^{e}=\frac{\left(1-\Gamma^{e}\left(\bar{\omega}_{t+1}^{e}\right)\right) R_{t+1}^{K}}{1-E_{t}\left\{\left(1-\Gamma^{F}\left(\bar{\omega}_{t+1}^{F}\right)\right)\left(\Gamma^{e}\left(\bar{\omega}_{t+1}^{e}\right)-\mu^{e} G^{e}\left(\bar{\omega}_{t+1}^{e}\right)\right) \frac{R_{t+1}^{K}}{\rho_{t} \phi_{t}^{F}}\right\}} n_{t}^{e}$

and, since a fraction $\left(1-\chi^{e}\right)$ of such wealth is left as a bequest to the next generation of entrepreneurs, the law of motion of entrepreneurs' aggregate initial net worth can be written as

$$
\begin{aligned}
& n_{t+1}^{e}=\left(1-\chi^{e}\right) \\
& \quad \times \frac{\left(1-\Gamma\left(\bar{\omega}_{t+1}^{e}\right)\right) R_{t+1}^{K}}{1-E_{t}\left\{\left(1-\Gamma^{F}\left(\bar{\omega}_{t+1}^{F}\right)\right)\left(\Gamma^{e}\left(\bar{\omega}_{t+1}^{e}\right)-\mu^{e} G^{e}\left(\bar{\omega}_{t+1}^{e}\right)\right) \frac{R_{t+1}^{K}}{\rho_{t} \phi_{t}^{F}}\right\}} n_{t}^{e} .
\end{aligned}
$$

\subsection{Bankers}

We model bankers in a very similar way to entrepreneurs: they belong to a sequence of overlapping generations of risk-neutral twoperiod-lived agents. Bankers have exclusive access to the opportunity of investing their wealth as banks' inside equity capital. Each generation of bankers inherits wealth in the form of bequests $n_{t}^{b}$ from the previous generation of bankers and leaves bequests $n_{t+1}^{b}$ to the subsequent one. Aggregate banker net worth determines, for a given capital requirement, the equilibrium-required rate of return on bank equity and hence the lending rates.

A banker born at time $t$ values his donations to the patient dynasty at $t+1$ ("dividends"), $c_{t+1}^{b}$, and the bequests left to the 
next cohort of bankers ("retained earnings"), $n_{t+1}^{b}$, according to the utility function $\left(c_{t+1}^{b}\right)^{\chi^{b}}\left(n_{t+1}^{b}\right)^{1-\chi^{b}}$, with $\chi^{b} \in(0,1)$. The banker who starts up at period $t$ receives a bequest from the previous generation of bankers and decides how to allocate this wealth as inside capital across the two classes of existing banks: the banks specializing in housing loans (the $H$ banks) and the banks specializing in entrepreneurial loans (the $F$ banks). There is a continuum of ex ante identical perfectly competitive banks of each class. The ex post gross return at $t+1$ on the inside equity invested in $H$ and $F$ banks at $t$ is denoted $\widetilde{\rho}_{t+1}^{H}$ and $\widetilde{\rho}_{t+1}^{F}$, respectively.

If a banker starting up with wealth $n_{t}^{b}$ invests an amount $e_{t}^{F}$ of inside equity in one or several $F$ banks, and the rest in one or several of the $H$ banks, his net worth after one period will be

$$
W_{t+1}^{b}=\widetilde{\rho}_{t+1}^{F} e_{t}^{F}+\widetilde{\rho}_{t+1}^{H}\left(n_{t}^{b}-e_{t}^{F}\right)
$$

which the banker will distribute by solving

$$
\max _{c_{t+1}^{b}, n_{t+1}^{b}}\left(c_{t+1}^{b}\right)^{\chi^{b}}\left(n_{t+1}^{b}\right)^{1-\chi^{b}}
$$

subject to

$$
c_{t+1}^{b}+n_{t+1}^{b} \leq W_{t+1}^{b} .
$$

Optimizing behavior yields the "dividend payment" rule

$$
c_{t+1}^{b}=\chi^{b} W_{t+1}^{b}
$$

and the "earnings retention" rule

$$
n_{t+1}^{b}=\left(1-\chi^{b}\right) W_{t+1}^{b},
$$

and an indirect utility equal to $W_{t+1}^{b}$.

The portfolio problem of the banker who starts up at $t$ can then be written as

$$
\max _{e_{t}^{F}} E_{t}\left(W_{t+1}^{b}\right)=E_{t}\left(\widetilde{\rho}_{t+1}^{F} e_{t}^{F}+\widetilde{\rho}_{t+1}^{H}\left(n_{t}^{b}-e_{t}^{F}\right)\right) .
$$


So, interior equilibria in which both classes of banks receive strictly positive inside equity from bankers will require the following equality to hold:

$$
E_{t} \widetilde{\rho}_{t+1}^{F}=E_{t} \widetilde{\rho}_{t+1}^{H}=\rho_{t},
$$

where $\rho_{t}$ denotes bankers' required expected gross rate of return on equity investments undertaken at time $t$. This expected return is endogenously determined in equilibrium, but both individual banks and bankers take it as given in their decisions. Specifically, $\rho_{t}$ plays an essential role in the bank participation constraints, (8) and (21), that appear in the problems of each class of final borrowers.

Finally, the law of motion of the initial wealth of each generation of bankers is

$$
n_{t+1}^{b}=\left(1-\chi^{b}\right)\left[\widetilde{\rho}_{t+1}^{F} e_{t}^{F}+\widetilde{\rho}_{t+1}^{H}\left(n_{t}^{b}-e_{t}^{F}\right)\right] .
$$

Therefore, under our assumptions, the risk-neutral bankers of each generation operate as in a one-period model (maximizing the expected one-period return on their initial wealth), but bank capital is a state variable important for aggregate dynamics (as, e.g., in Gertler and Kiyotaki 2010). As in the case of entrepreneurs, assuming that bankers directly derive utility from transferring $c_{t+1}^{b}$ to the savings households will allow us to focus the welfare analysis on households' lifetime utility without neglecting the consumption capacity associated with bankers' unretained profits.

\subsection{Banks}

The banks which issue the equity bought by bankers are institutions specialized in extending either mortgages or corporate loans. A bank lasts for one period only: it is an investment project created at $t$ and liquidated at $t+1$. We assume a continuum of banking institutions of each class $j=H, F$. The equity payoffs $\pi_{t+1}^{j}$ generated by a representative of class $j$ after its period of operation is given by the positive part of the difference between the returns from its loans and the repayments due to its deposits:

$$
\pi_{t+1}^{j}=\max \left[\omega_{t+1}^{j} \tilde{R}_{t+1}^{j} b_{t}^{j}-R_{t}^{D} d_{t}^{j}, 0\right],
$$


where $b_{t}^{j}$ and $d_{t}^{j}$ are the loans extended and the deposits taken by the bank at $t$, respectively, $R_{t}^{D}$ is the gross interest rate paid on the deposits taken at $t$ (which is uniform across all banks given the presence of deposit insurance and the assumption that depositors cannot assign individualize estimates of the probability of failure to each bank), and $\tilde{R}_{t+1}^{j}$ denotes the realized return on a well-diversified portfolio of loans of class $j$. The max operator reflects the fact that the shareholders of the bank enjoy limited liability, so their payoffs cannot be negative.

The bank's idiosyncratic failure risk comes from the existence of an idiosyncratic portfolio return shock $\omega_{t+1}^{j}$ which is i.i.d. across the banks of class $j$ and is assumed to follow a log-normal distribution with a mean of one and a distribution function $F^{j}\left(\omega_{t+1}^{j}\right) 24$ We also allow for an aggregate shock to the bank's idiosyncratic failure riski.e., a bank risk shock - that, similarly to the other aggregate sources of uncertainty featured by the model, follows an AR(1) process.

Bank default is driven by fluctuations in the aggregate loan return $\tilde{R}_{t+1}^{j}$ (itself driven by firms' or households' default rates) and the bank-idiosyncratic shock $\omega_{t+1}^{j}$. When a bank fails, its equity is written down to zero and its deposits are taken over by the DIA, which pays out all deposits in full. The DIA partly recoups this by taking over the failed bank's loan portfolio minus resolution costs, which are assumed to be a $\mu^{j}$ fraction of total bank assets.

The bank also faces a regulatory capital constraint:

$$
e_{t}^{j} \geq \phi_{t}^{j} b_{t}^{j}
$$

where $\phi_{t}^{j}$ is the potentially time-varying capital-to-asset ratio of banks of class $j$. Thus, the bank is restricted by regulation to back with equity funding at least a fraction $\phi_{t}^{j}$ of the loans made at $t$. It is possible to show that in equilibrium the constraint is binding, so that the loans can be written as $b_{t}^{j}=e_{t}^{j} / \phi_{t}^{j}$ and the deposits as $d_{t}^{j}=\left(1-\phi_{t}^{j}\right) e_{t}^{j} / \phi_{t}^{j}$. Allowing the capital requirement $\phi_{t}^{j}$ to vary across different classes of banks is consistent with thinking of them as

\footnotetext{
${ }^{24}$ The fact that the shock has mean of one and is i.i.d. across banks makes it equivalent to a redistribution of gross loan returns across banks, which may be interpreted as a reduced form for the existence of imperfect diversification, e.g., due to unmodeled regional or industry specialization.
} 
risk based (like under Basel III) or as sectoral requirements serving as tools of macroprudential policy.

Note that the role of the regulatory capital requirement is to compensate for the limited liability distortions described earlier. A higher capital requirement forces banks to get funded with a larger share of equity financing, which is more expensive than deposit financing because of two reasons: (i) equity does not enjoy the protection of deposit insurance, (ii) bankers' wealth is limited and in equilibrium appropriates some scarcity rents. Moreover, lower leverage reduces the probability of bank default and hence the overall size of the deposit insurance subsidy. The implication is an increase in the loan rates at which banks are willing to lend (i.e., a tightening of banks' participation constraints in the problems of the borrowing households and entrepreneurs) and, in equilibrium, a more restricted access to credit for households and entrepreneurs.

Let $\bar{\omega}_{t+1}^{j}$ denote the threshold realization of $\omega_{t+1}^{j}$ below which the bank fails because the realized return on its loan portfolio is lower than its deposit repayment obligations:

$$
\bar{\omega}_{t+1}^{j} \tilde{R}_{t+1}^{j} b_{t}^{i j} \equiv R_{t}^{D} d_{t}^{i j} .
$$

Using our previous expressions for $b_{t}^{j}$ and $d_{t}^{j}$, we can write the threshold as

$$
\bar{\omega}_{t+1}^{j}=\left(1-\phi_{t}^{j}\right) \frac{R_{t}^{D}}{\tilde{R}_{t+1}^{j}},
$$

that is, the product of the leverage ratio $1-\phi_{t}^{j}$ and the spread between the realized gross loan return and the gross deposit rate, $\tilde{R}_{t+1}^{j} / R_{t}^{D}$.

The equity payoffs in (29) can then be rewritten as

$$
\begin{aligned}
\pi_{t+1}^{j}= & \max \left[\omega_{t+1}^{j}-\bar{\omega}_{t+1}^{j}, 0\right] \frac{\tilde{R}_{t+1}^{j}}{\phi_{t}^{j}} e_{t}^{j} \\
= & {\left[\int_{\bar{\omega}_{t+1}^{j}}^{\infty} \omega_{t+1}^{j} f^{j}\left(\omega_{t+1}^{j}\right) d \omega_{t+1}^{j}-\bar{\omega}_{t+1}^{j} \int_{\bar{\omega}_{t+1}^{j}}^{\infty} f^{j}\left(\omega_{t+1}^{j}\right) d \omega_{t+1}^{j}\right] } \\
& \times \frac{\tilde{R}_{t+1}^{j}}{\phi_{t}^{j}} e_{t}^{j},
\end{aligned}
$$


where $f^{j}\left(\omega_{t+1}^{j}\right)$ denotes the density distribution of $\omega_{t+1}^{j}$ conditional on the information available when the loans are originated at time $t$. Hence $F^{j}\left(\bar{\omega}_{t+1}^{j}\right)$ is the probability of default of a bank of class $j$ (conditional upon the realization of the aggregate loan return $\tilde{R}_{t+1}^{j}$, which enters this expression through $\bar{\omega}_{t+1}^{j}$ ).

Following BGG, it is useful to define

$$
\Gamma^{j}\left(\bar{\omega}_{t+1}^{j}\right)=\int_{0}^{\bar{\omega}_{t+1}^{j}} \omega_{t+1}^{j} f^{j}\left(\omega_{t+1}^{j}\right) d \omega_{t+1}^{j}+\bar{\omega}_{t+1}^{j} \int_{\bar{\omega}_{t+1}^{F}}^{\infty} f^{j}\left(\omega_{t+1}^{j}\right) d \omega_{t+1}^{j}
$$

and

$$
G^{j}\left(\bar{\omega}_{t+1}^{j}\right)=\int_{0}^{\bar{\omega}_{t+1}^{j}} \omega_{t+1}^{j} f^{j}\left(\omega_{t+1}^{j}\right) d \omega_{t+1}^{j},
$$

which denotes the share of total bank assets which belong to banks that end up in default. Thus $\mu^{j} G^{j}\left(\bar{\omega}_{t+1}^{j}\right)$ is the total cost of bank default expressed as a fraction of total bank assets.

Using this notation we can write

$$
\pi_{t+1}^{j}=\frac{\left[1-\Gamma^{j}\left(\bar{\omega}_{t+1}^{j}\right)\right] \tilde{R}_{t+1}^{j}}{\phi_{t}^{j}} e_{t}^{j}
$$

and define the ex post gross rate of return on equity invested in a bank of type $j$ as

$$
\widetilde{\rho}_{t+1}^{j}=\frac{\left[1-\Gamma^{j}\left(\bar{\omega}_{t+1}^{j}\right)\right] \tilde{R}_{t+1}^{j}}{\phi_{t}^{j}} .
$$

For completeness, notice that derivations in prior sections imply the following expressions for $\tilde{R}_{t+1}^{j}, j=H, F$ :

$$
\begin{aligned}
& \tilde{R}_{t+1}^{H}=\left(\Gamma^{m}\left(\frac{x_{t}^{m}}{R_{t+1}^{H}}\right)-\mu^{m} G^{m}\left(\frac{x_{t}^{m}}{R_{t+1}^{H}}\right)\right) \frac{R_{t+1}^{H} q_{t}^{H} h_{t}^{m}}{b_{t}^{m}} \\
& \tilde{R}_{t+1}^{F}=\left(\Gamma^{e}\left(\frac{x_{t}^{e}}{R_{t+1}^{K}}\right)-\mu^{e} G^{e}\left(\frac{x_{t}^{e}}{R_{t+1}^{K}}\right)\right) \frac{R_{t+1}^{K} q_{t}^{K} k_{t}}{q_{t}^{K} k_{t}-n_{t}^{e}}
\end{aligned}
$$


Finally, the aggregate default rate for the banking system $P D_{t}^{b}$, which enters in (3), is given by

$$
P D_{t}^{b}=\frac{d_{t-1}^{H} P D_{t}^{H}+d_{t-1}^{F} P D_{t}^{F}}{d_{t-1}^{H}+d_{t-1}^{F}} .
$$

\subsection{Consumption Good Production}

The consumption good is produced by perfectly competitive firms which combine capital rented from entrepreneurs, $k_{t-1}$, and labor supplied by patient and impatient households, $l_{t}$, using a standard Cobb-Douglas production function:

$$
y_{t}=A_{t} k_{t-1}^{\alpha} l_{t}^{1-\alpha},
$$

where $\alpha$ is an elasticity parameter and $A_{t}$ is total factor productivity (TFP) following an $\mathrm{AR}(1)$ process:

$$
\ln A_{t}=\rho^{A} \ln A_{t-1}+\varepsilon_{t}^{A},
$$

where $\rho^{A}$ is the persistency parameter and $\varepsilon_{t}^{A}$ is an i.i.d. shock with variance $\sigma_{A}^{2}$.

Optimality in the use of the capital and labor input requires

$$
r_{t}^{K}=\alpha \frac{y_{t}}{k_{t-1}}
$$

and

$$
w_{t}=(1-\alpha) \frac{y_{t}}{l_{t}}
$$

\subsection{Capital Good and Housing Production}

We model capital-good-producing firms and housing-producing firms symmetrically. They produce new units of capital and housing from the consumption good and sell them to entrepreneurs and households, respectively, at prices $q_{t}^{K}$ and $q_{t}^{H}$. These firms are owned by the patient households and their technology is subject to adjustment costs. In order to produce $I_{t}=k_{t}-\left(1-\delta_{t}\right) k_{t-1}$ of new capital and $I_{t}^{H}=h_{t}-\left(1-\delta_{t}^{H}\right) h_{t-1}$ of new housing, the corresponding representative firm needs to spend resources of 


$$
\left[1+g\left(\frac{I_{t}}{I_{t-1}}\right)\right] I_{t} \quad \text { and } \quad\left[1+g^{H}\left(\frac{I_{t}^{H}}{I_{t-1}^{H}}\right)\right] I_{t}^{H},
$$

where $g(\cdot)$ and $g^{H}(\cdot)$ are the corresponding investment adjustment cost functions that satisfy the standard properties. Since these firms are owned by the patient households, their objective is to choose investment $I_{t}$ and $I_{t}^{H}$ in order to maximize

$$
E_{t} \sum_{i=0}^{\infty}\left(\beta^{s}\right)^{i} \frac{c_{t}^{s}}{c_{t+i}^{s}}\left\{q_{t+i}^{K} I_{t+i}-\left[1+g\left(\frac{I_{t+i}}{I_{t+i-1}}\right)\right] I_{t+i}\right\}
$$

and

$$
E_{t} \sum_{i=0}^{\infty}\left(\beta^{s}\right)^{i} \frac{c_{t}^{s}}{c_{t+i}^{s}}\left\{q_{t+i}^{H} I_{t+i}^{H}-\left[1+g^{H}\left(\frac{I_{t+i}^{H}}{I_{t+i-1}^{H}}\right)\right] I_{t+i}^{H}\right\}
$$

respectively.

\section{Market Clearing, DIA, and Capital Requirements}

\subsection{Consumption Good Market}

In the goods market, total output $y_{t}$ should equal the total consumption demands of the savers $c_{t}^{s}$ and the borrowers $c_{t}^{m}$, plus the resources absorbed in the production of the new capital $I_{t}$ and the new housing $I_{t}^{H}$, plus the resources lost in the recovery by lenders of the proceeds associated with defaulted bank loans, in transaction costs by depositors at failed banks, or by the deposit insurance agency in the recovery of assets from failed banks:

$$
\begin{aligned}
y_{t}= & c_{t}^{s}+c_{t}^{m}+\left[1+g\left(\frac{I_{t}}{I_{t-1}}\right)\right] I_{t}+\left[1+g^{H}\left(\frac{I_{t}^{H}}{I_{t-1}^{H}}\right)\right] I_{t}^{H} \\
& +\mu^{e} G^{e}\left(\bar{\omega}_{t}^{e}\right) R_{t}^{K} q_{t-1}^{K} k_{t-1}+\mu^{m} G^{m}\left(\frac{x_{t-1}^{m}}{R_{t}^{H}}\right) R_{t}^{H} q_{t-1}^{H} h_{t-1}^{m} \\
& +\gamma P D_{t}^{b} R_{t-1}^{D} d_{t-1}+\mu^{B}\left[G^{H}\left(\bar{\omega}_{t}^{H}\right) \widetilde{R}_{t}^{H}\left(\frac{q_{t-1}^{H} h_{t-1}^{m} x_{t-1}^{m}}{R_{t-1}^{m}}\right)\right. \\
& \left.+G^{F}\left(\bar{\omega}_{t}^{F}\right) \widetilde{R}_{t}^{F}\left[q_{t-1}^{K} k_{t-1}-\left(1-\chi^{e}\right) W_{t-1}^{e}\right]\right] .
\end{aligned}
$$


For reporting purposes, we will also consider a measure of net output, $\widetilde{y}_{t}$, which is net of the expenditure associated to default:

$$
\widetilde{y}_{t}=c_{t}^{s}+c_{t}^{m}+\left[1+g\left(\frac{I_{t}}{I_{t-1}}\right)\right] I_{t}+\left[1+g^{H}\left(\frac{I_{t}^{H}}{I_{t-1}^{H}}\right)\right] I_{t}^{H} .
$$

This output measure is arguably more important when analyzing welfare, since costs associated with default do not increase household utility.

\subsection{Labor Market}

The total demand for households' labor by the consumption-goodproducing firms, $(1-\alpha) \frac{y_{t}}{w_{t}}$, must be equal to the labor supply of the two types of households:

$$
(1-\alpha) \frac{y_{t}}{w_{t}}=l_{t}^{s}+l_{t}^{m}
$$

\subsection{Capital Good Market}

The stock of the capital good evolves according to $k_{t}=\left(1-\delta_{t}\right) k_{t-1}+$ $I_{t}$, and market clearing requires $k_{t}$ to equal the demand for this good coming from entrepreneurs at $t$ (which in turn equals the amount of capital rented to the consumption-good-producing firms at $t+1$ ).

\subsection{Housing Good Market}

The stock of housing evolves according to $h_{t}=\left(1-\delta_{t}^{H}\right) h_{t-1}+I_{t}^{H}$, and market clearing requires $h_{t}=h_{t}^{s}+h_{t}^{m}$.

\subsection{Deposit Market}

The deposits held by the saving households $\left(d_{t}\right)$ must equal the sum of the demand for deposit funding from the banks making loans to households, $d_{t}^{H}=\left(1-\phi_{t}^{H}\right)\left(q_{t}^{H} h_{t}^{m} x_{t}^{e} / R_{t}^{m}\right)$, and from the banks making loans to entrepreneurs, $d_{t}^{F}=\left(1-\phi_{t}^{F}\right)\left[q_{t}^{K} k_{t}-\left(1-\chi^{e}\right) W_{t}^{e}\right]$ :

$$
d_{t}=\left(1-\phi_{t}^{F}\right)\left[q_{t}^{K} k_{t}-\left(1-\chi^{e}\right) W_{t}^{e}\right]+\left(1-\phi_{t}^{H}\right)\left(\frac{q_{t}^{H} h_{t}^{m} x_{t}^{m}}{R_{t}^{m}}\right) .
$$




\subsection{Banks' Inside Equity Market}

The total equity provided by bankers $\left(n_{t}^{b}=\left(1-\chi^{b}\right) W_{t}^{b}\right)$ must equal the sum of the demand for bank equity from the banks making loans to households, $e_{t}^{H}=\phi_{t}^{H} b_{t}^{H}=\phi_{t}^{H}\left(q_{t}^{H} h_{t}^{m} x_{t}^{e} / R_{t}^{m}\right)$, and from the banks making loans to entrepreneurs, $e_{t}^{F}=\phi_{t}^{F} b_{t}^{F}=$ $\phi_{t}^{F}\left[q_{t}^{K} k_{t}-\left(1-\chi^{e}\right) W_{t}^{e}\right]$ :

$$
\left(1-\chi^{b}\right) W_{t}^{b}=\phi_{t}^{F}\left[q_{t}^{K} k_{t}-\left(1-\chi^{e}\right) W_{t}^{e}\right]+\phi_{t}^{H}\left(\frac{q_{t}^{H} h_{t}^{m} x_{t}^{m}}{R_{t}^{m}}\right) .
$$

\subsection{Deposit Insurance Agency}

The losses caused to the DIA by the failing $H$ and $F$ banks are given by

$$
T_{t}^{H}=\left[\bar{\omega}_{t}^{H}-\Gamma^{H}\left(\bar{\omega}_{t}^{H}\right)+\mu^{H} G^{H}\left(\bar{\omega}_{t}^{H}\right)\right] \widetilde{R}_{t}^{H}\left(\frac{q_{t-1}^{H} h_{t-1}^{m} x_{t-1}^{m}}{R_{t-1}^{m}}\right)
$$

and

$T_{t}^{F}=\left[\bar{\omega}_{t}^{F}-\Gamma^{F}\left(\bar{\omega}_{t}^{F}\right)+\mu^{F} G^{F}\left(\bar{\omega}_{t}^{F}\right)\right] \widetilde{R}_{t}^{F}\left[q_{t-1}^{K} k_{t-1}-\left(1-\chi^{e}\right) W_{t-1}^{e}\right]$, respectively, and covering them with the lump-sum tax imposed on patient households requires $T_{t}=T_{t}^{H}+T_{t}^{F}$.

\subsection{Bank Capital Requirements}

The regulatory capital requirement $\phi_{t}^{j}$ applicable to each class of banks is generally specified as follows:

$$
\phi_{t}^{j}=\bar{\phi}_{0}^{j}+\bar{\phi}_{1}^{j}\left[\log \left(b_{t}\right)-\log (\bar{b})\right],
$$

where $\bar{\phi}_{0}^{j}$ is the structural capital requirement (equal to its steadystate level) and the additional term captures the cyclically dependent part of the requirement due, e.g., to the existence of a countercyclical capital buffer (CCB) that depends on the state of the economy, as in Basel III 25 For computational convenience, we model the

\footnotetext{
${ }^{25}$ To save on notation, when analyzing time-invariant capital requirements below $\left(\bar{\phi}_{1}^{j}=0\right)$, we will refer to $\bar{\phi}_{0}^{j}$ by simply $\phi^{j}$.
} 
countercyclical adjustment of the capital requirements as an additive term that linearly depends on the deviations of total bank credit, $b_{t}=b_{t}^{H}+b_{t}^{F}$, from its steady-state level, $\bar{b}=\bar{b}^{H}+\bar{b}^{F} 26$

\section{Baseline Parameterization}

The baseline parameterization of the model is partly based on values that are standard in the literature and partly on choices that, without being implausible, constitute only a first attempt to illustrate the qualitative and potential quantitative properties of the model. For most parameters of the households and entrepreneurs sectors, we rely on Gerali et al. (2010) and Darracq-Pariès, Kok Sørensen, and Rodriguez-Palenzuela (2011), which both develop DSGE models of the euro area.

Capital requirements are set at a benchmark level of 8 percent for corporate loans (compatible with the full weight level of Basel I and the treatment of non-rated corporate loans in Basel II and III) and 4 percent for mortgage loans (compatible with their 50 percent risk weight in Basel I). Parameters determining the probabilities of default of the various classes of loans are chosen so as to make their baseline steady-state values equivalent to annual rates of 0.35 percent for mortgages, 3 percent for entrepreneurial loans, and 2 percent for banks. The bankruptcy cost parameters imply losses of 10 percent of face value of deposits for depositors at failed banks and of 30 percent of asset value for creditors repossessing assets from defaulting borrowers. Table 1 reports all the parameter values. One period in the model corresponds to one quarter in calendar time.

\section{Results}

First, we analyze the long-run implications of different levels of capital requirements. Second, we analyze the effects of shocks to aggregate productivity, capital depreciation, and bank risk on the dynamics around the steady state. We compare the transmission of shocks

\footnotetext{
${ }^{26}$ So in our formulation, the total capital charge may both increase or decrease relative to its time-invariant benchmark $\bar{\phi}_{0}^{j}$. In contrast, in Basel III the CCB is a non-negative add-on to the structural capital requirements (core equity tier 1 plus the capital conservation buffer).
} 


\section{Table 1. Baseline Parameterization of the Model}

\begin{tabular}{|l|c|c|}
\hline Description & Par. & Value \\
\hline Patient Household Discount Factor & $\beta^{s}$ & 0.995 \\
Impatient Household Discount Factor & $\beta^{m}$ & 0.98 \\
Patient Household Utility Weight of Housing & $v^{m}$ & 0.25 \\
Impatient Household Utility Weight of Housing & $v^{s}$ & 0.25 \\
Patient Household Marginal Disutility of Labor & $\varphi^{s}$ & 1.00 \\
Impatient Household Marginal Disutility of Labor & $\varphi^{m}$ & 1.00 \\
Inverse of Frisch Elasticity of Labor & $\eta$ & 1.00 \\
Depositor Cost of Bank Default & $\gamma$ & 0.10 \\
Variance of Household Idiosyncratic Shocks & $\sigma_{m}^{2}$ & 0.08 \\
Household Bankruptcy Cost & $\mu^{m}$ & 0.30 \\
Dividend Payout of Entrepreneurs & $\chi^{e}$ & 0.05 \\
Variance of Entrepreneurial Risk Shock & $\sigma_{e}^{2}$ & 0.12 \\
Entrepreneur Bankruptcy Cost & $\mu^{e}$ & 0.30 \\
Capital Requirement for Mortgage Loans & $\phi^{H}$ & 0.04 \\
Capital Requirement for Corporate Loans & $\phi^{F}$ & 0.08 \\
Mortgage Bank Bankruptcy Cost & $\mu^{H}$ & 0.30 \\
Corporate Bank Bankruptcy Cost & $\mu^{F}$ & 0.30 \\
Capital Share in Production & $\alpha$ & 0.30 \\
Capital Depreciation Rate & $\delta^{K}$ & 0.025 \\
Capital Adjustment Cost Parameter & $\psi^{K}$ & 2.00 \\
Housing Depreciation Rate & $\delta^{H}$ & 0.01 \\
Housing Adjustment Cost Parameter & $\psi^{H}$ & 2.00 \\
Shocks Persistence & $\rho$ & 0.90 \\
Dividend Payout of Bankers & $\chi^{b}$ & 0.05 \\
Variance of Mortgage Bank Risk Shock & $\sigma_{H}^{2}$ & 0.0119 \\
Variance of Corporate Bank Risk Shock & $\sigma_{F}^{2}$ & 0.0238 \\
\hline
\end{tabular}

under the baseline capital requirements $\left(\bar{\phi}_{0}^{F}=\phi^{F}=0.08 ; \bar{\phi}_{0}^{H}=\right.$ $\left.\phi^{H}=0.04\right)$ and under higher capital requirements.

\subsection{Steady-State Effects of Capital Requirements}

In the following, we investigate the relationship between different levels of capital requirements, $\phi^{F}$ and $\phi^{H}$, and welfare in steady state. The welfare function for each agent is given by the conditional expectation of the corresponding lifetime utility as of a reference period $t$. Due to the presence of several classes of agents in the 
model, we consider a (utilitarian) social welfare measure that aggregates the individual welfare of the representative agents of each class. We will focus on households only.

Specifically, we compute the welfare gains associated with any particular policy change as a weighted average of the welfare gains of each household dynasty, the patient $(j=s)$ and the impatient $(j=m)$, measured in consumption-equivalent terms, i.e., the percentage increase in steady-state consumption, $\Delta^{j}$, that would make the welfare of such dynasty under the baseline policy $\left(\phi^{F}=\right.$ $\left.0.08 ; \phi^{H}=0.04\right)$ equal to the welfare under alternative values of $\phi^{F}$ and $\phi^{H}$. And we weight each individual $\Delta^{j}$ with the share of dynasty $j$ in aggregate consumption under the baseline policy. So the reported social welfare gains are given by

$$
\Delta W \equiv \frac{c_{0}^{s}}{c_{0}^{s}+c_{0}^{m}} \Delta^{s}+\frac{c_{0}^{m}}{c_{0}^{s}+c_{0}^{m}} \Delta^{m}
$$

where $c_{0}^{j}$ denotes the steady-state consumption of dynasty $j$ under the baseline policy.

Importantly, although entrepreneurs and bankers do not enter into our social welfare criterion on their own right, the contribution of entrepreneurial and bank profits to aggregate consumption capacity is taken into account through the donations (lump-sum transfers) that these agents have been assumed to make to the patient dynasty 27

We start by providing a first key result of our paper, namely the steady-state relationship between the capital requirement ratio and social welfare gains. Figure 1 displays the steady-state social welfare gains $\Delta W$ associated with capital requirements higher than the baseline value. The hump-shaped relationship between higher capital requirements and social welfare gains reflects the presence of a trade-off. Higher capital requirements reduce the implicit subsidy to banks associated with limited liability and deposit insurance. Thus, in comparison with the baseline policy, an increase in capital requirements implies both a reduction in the supply of loans (which

\footnotetext{
${ }^{27}$ We have also considered a version of the model in which these transfers are split between the two dynasties, and the results are qualitatively and quantitatively very similar.
} 


\section{Figure 1. Steady-State Welfare Depending on the Capital Requirement}

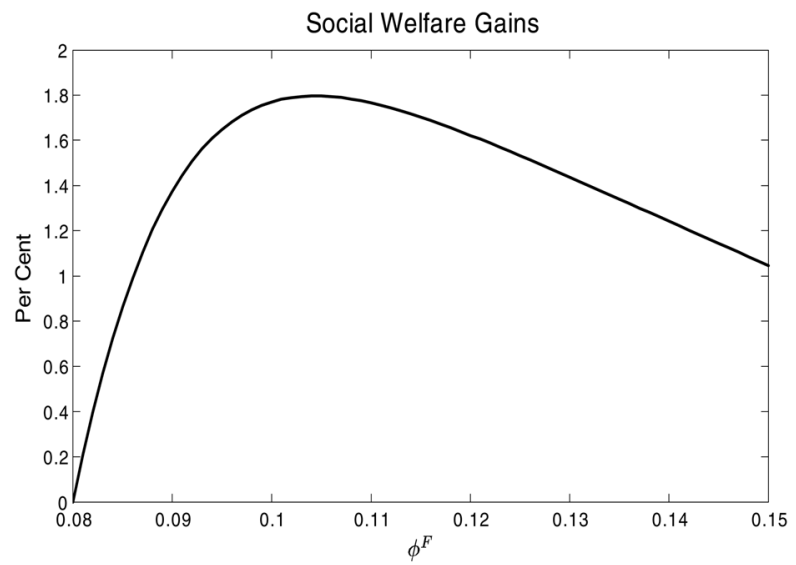

Notes: Social welfare gains are the weighted average of the steady-state gains (losses) experienced by the representative agent of each type of household (patient and impatient) measured in certainty-equivalent consumption terms. The weights are given by the consumption shares of each class of households under the initial reference policy $\left(\phi^{F}=0.08, \phi^{H}=0.04\right)$. Alternative policies involve the value of $\phi^{F}$ described in the horizontal axes and $\phi^{H}=\phi^{F} / 2$.

are provided at higher interest rates) and a lower average default rate of banks (see figure 2). The implied reduction in the social cost of banks' default has a positive effect on economic activity, notably consumption and investment (figure 3). This effect dominates at first. In contrast, the negative effects on economic activity coming from the reduction in the supply of credit to the economy dominate when capital requirements are high enough (actually, at levels in which banks' default rate is virtually zero). Note that the initial increase in credit displayed in figure 4 is due to the reduction in the cost of deposit funding. Indeed, banks are less fragile and depositors require a lower premium in compensation for their anticipated costs of bank default.

Under the calibration reported in section 5, we find that the optimal capital requirement should be around 10.5 percent for business loans and 5.25 percent for mortgages (50 percent risk weight). This is consistent with Bank for International Settlements (2010) and 
Figure 2. Steady-State Values Depending on the Capital Requirement (I)
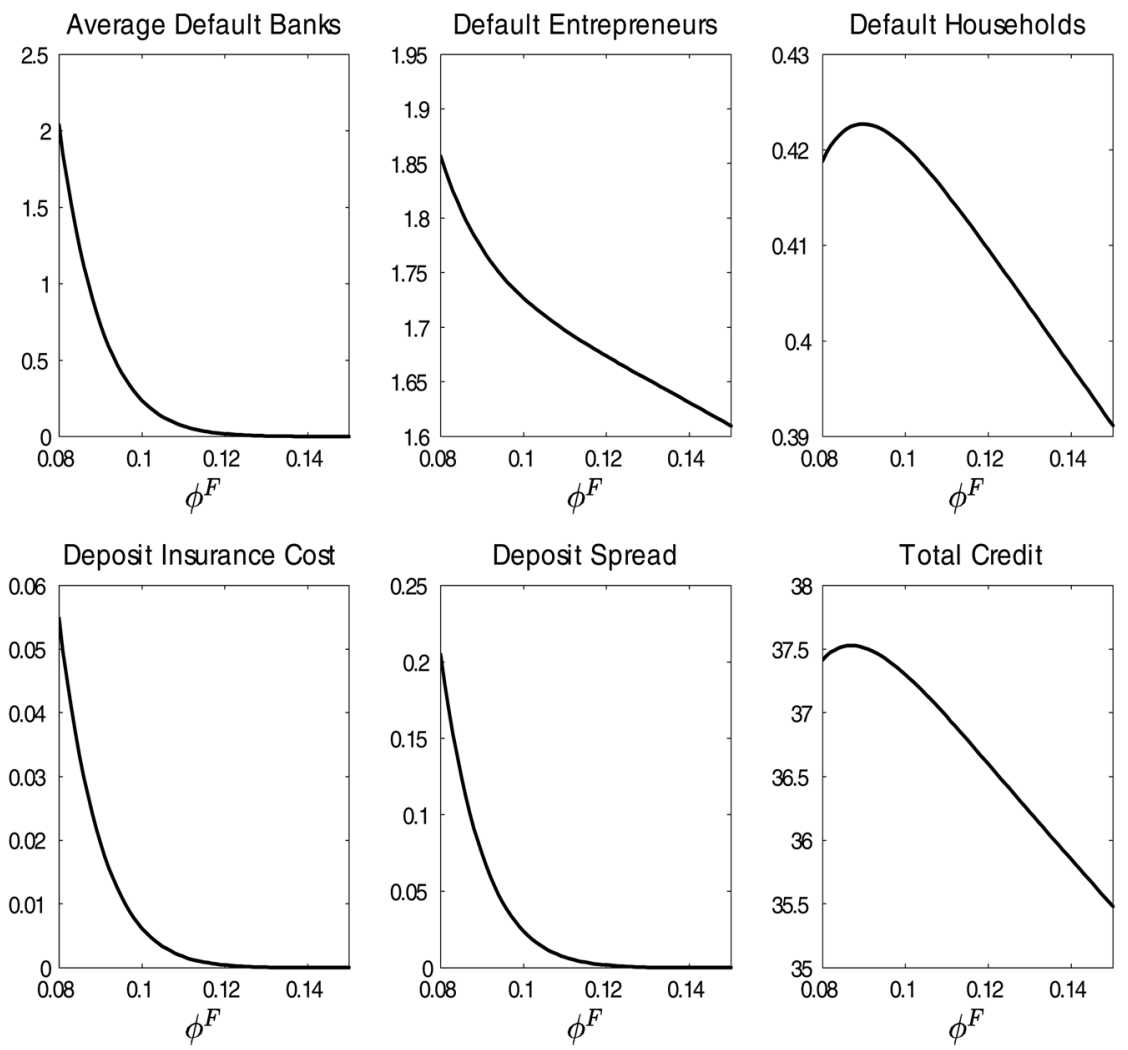

Notes: Alternative policies involve the value of $\phi^{F}$ described in the horizontal axes and $\phi^{H}=\phi^{F} / 2$.

Miles, Yang, and Marcheggiano (2013). However, our model would not support higher capital ratios, such as the value of 25 percent recently suggested by Admati and Hellwig (2013). In our model, too-high capital requirements would excessively restrict credit availability while reducing default rates only marginally, resulting in a net welfare loss.

Overall, our setup provides a clear rationale for capital regulation, which arises as a welfare-improving response to the excessive 


\section{Figure 3. Steady-State Values Depending on the Capital Requirement (II)}
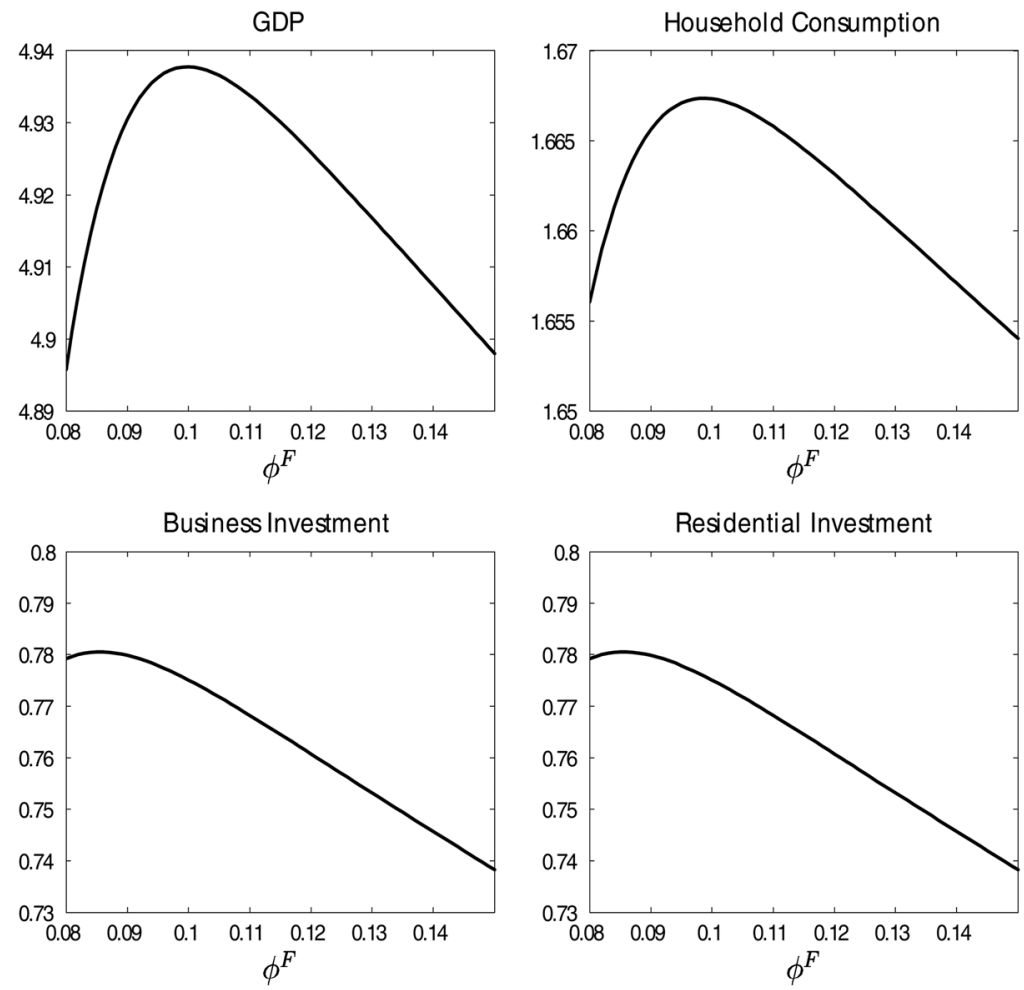

Notes: Alternative policies involve the value of $\phi^{F}$ described in the horizontal axes and $\phi^{H}=\phi^{F} / 2$.

leverage otherwise induced by deposit insurance (among banks and also at the sectors borrowing from them). Importantly, banks' equity funding in the model is limited by the wealth endogenously accumulated by the bankers who own and manage the banks. So capital requirements reduce bank leverage, bank failure risk, and the implicit subsidies associated with deposit insurance, and, simultaneously, they also force the banks to make a greater use of bankers' limited wealth. In the short run, this second aspect makes capital requirements have a potential impact on the cost of equity funding (due to the scarcity of bankers' wealth). However, over time, bankers 


\section{Figure 4. Steady-State Values Depending on the Capital Requirement (III)}
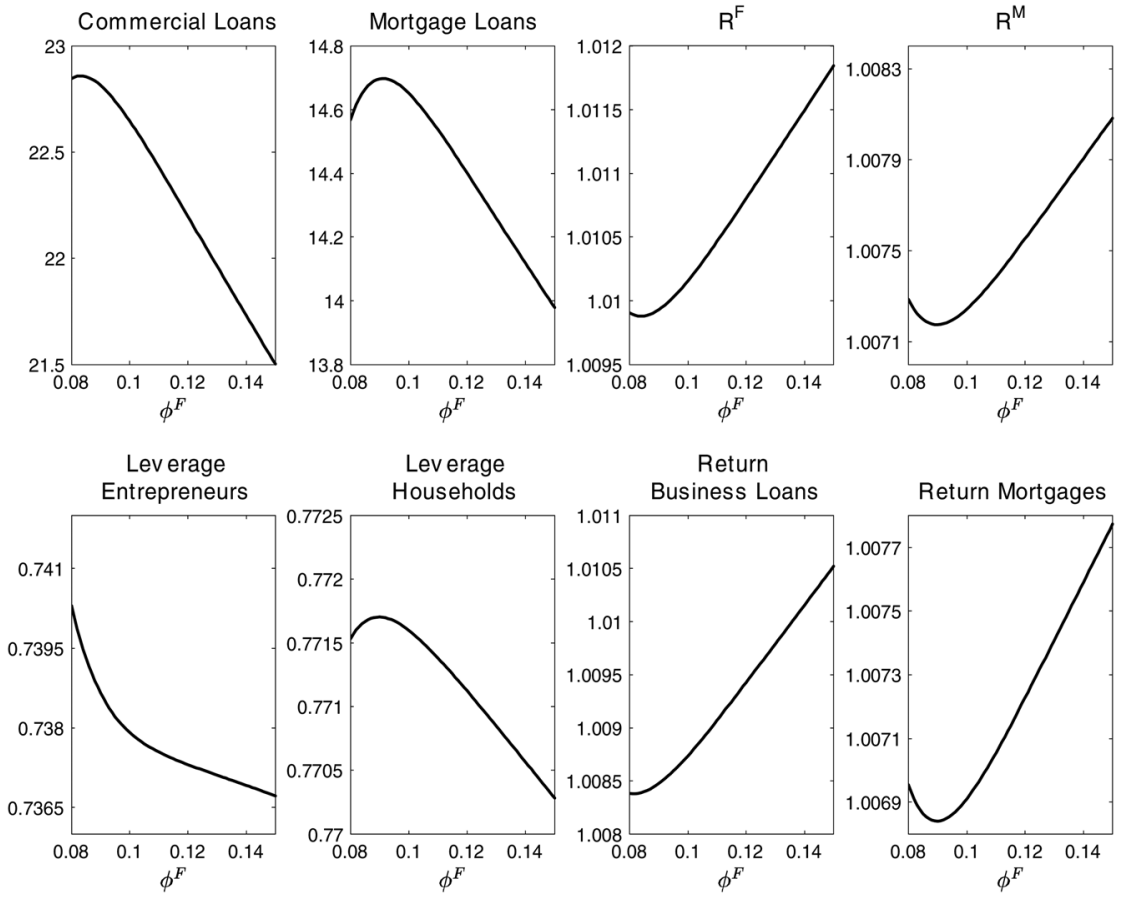

Notes: Alternative policies involve the value of $\phi^{F}$ described in the horizontal axes and $\phi^{H}=\phi^{F} / 2$.

accumulate additional wealth, and the cost of equity funding in the new steady state is the same as under lower requirements. So the steady-state results are entirely due to banks' lower leverage and their possibly higher weighted average cost of funds.

\subsection{Capital Requirements and Shock Propagation}

The second set of results concerns the model responses to structural shocks, in a first-order approximation around the deterministic steady state. Figure 5 reports the response of GDP to a 1 percent decline in aggregate productivity. It compares the response of GDP under alternative parameterizations of the model. We find that 


\section{Figure 5. Impulse Responses after a Negative TFP Shock (I): The Effect on GDP under Different Assumptions on the Bank Capital Requirement and Bank Risk}

\section{Bank Risk}

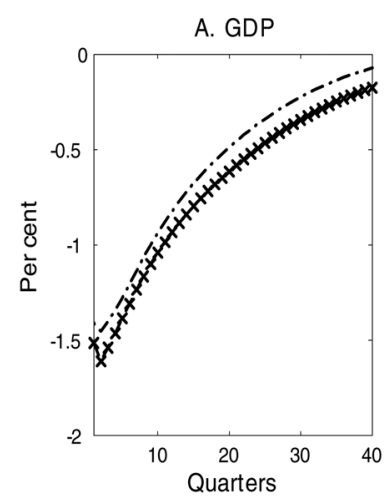

- * Benchmark

-.-.-High Capital Requirement

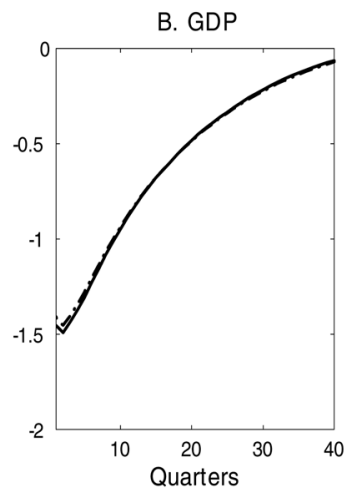

No Bank Default
-.-.High Capital Requirement

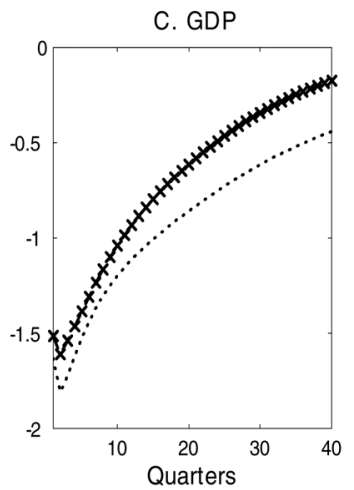

- * Benchmark High Financial Distress

Notes: "Benchmark" describes the economy with $\phi^{F}=0.08$ and $\phi^{H}=0.04$. "High capital requirement" describes the economy with $\phi^{F}=0.105$ and $\phi^{H}=$ 0.0525. "High financial distress" describes an economy with a variance of the idiosyncratic shock to banks' performance higher than in the baseline parameterization. "No bank default" describes an economy in which the variance of the idiosyncratic shock to bank performance is zero. GDP is defined as net of bankruptcy costs due to default. It is therefore a measure of "net output."

higher capital requirements (i) mitigate the effects of a reduction in aggregate productivity (panel A), and (ii) mimic the dynamics of a no-bank-default economy (panel B). Comparing the benchmark economy with an economy with higher financial distress in the banking sector (i.e., higher bank risk as captured by $\sigma^{F}$ and $\sigma^{H}$ ), we also find that high financial distress greatly exacerbates the negative effect of productivity shocks (panel C).

Figures 6 and 7 report on the effect of a negative productivity shock on the key variables in the model. Each graph with the impulse response functions contains four lines. We report the responses of the variables in the benchmark economy, i.e., $\phi^{F}=0.08$ and $\phi^{H}=0.04$ (starred line) and in the economy with capital requirements closer 


\section{Figure 6. Impulse Responses after a Negative TFP Shock (II)}
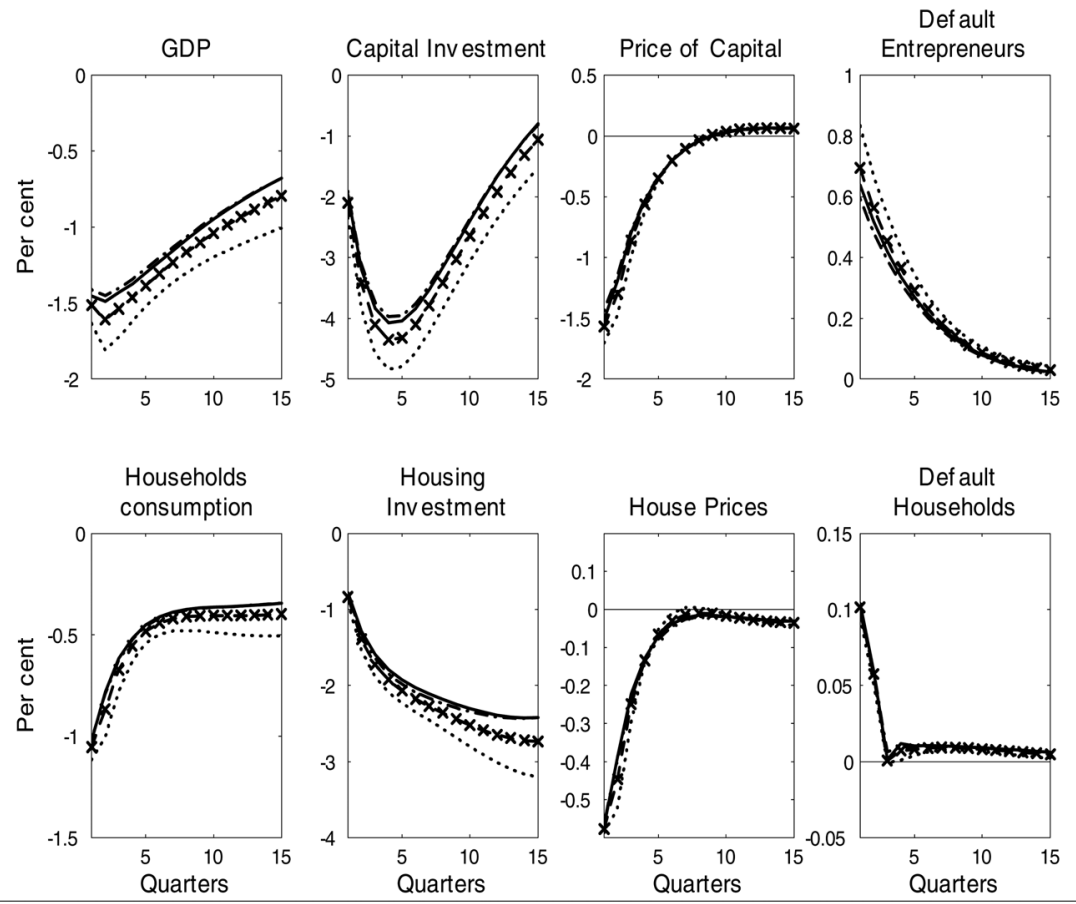

- * - Benchmark $\cdot-\cdot-\cdot$ High Capital Requirement $\cdot . . . .$. High Financial Distress — No Bank Def ault

Notes: "Benchmark" describes the economy with $\phi^{F}=0.08$ and $\phi^{H}=0.04$. "High capital requirement" describes the economy with $\phi^{F}=0.105$ and $\phi^{H}=0.0525$. "High financial distress" describes an economy with a variance of the idiosyncratic shock to banks' performance higher than in the baseline parameterization. "No bank default" describes an economy in which the variance of the idiosyncratic shock to bank performance is zero. GDP is defined as net of bankruptcy costs due to default. It is therefore a measure of "net output."

to the welfare maximizing ones, i.e., $\phi^{F}=0.105$ and $\phi^{H}=0.0525$ (dashed line). Further, we also consider a parameterization with no bank default, i.e., $\sigma^{F}=\sigma^{H} \approx 0$ (solid line) and with high financial distress, i.e., $\sigma^{F}=0.0238$ and $\sigma^{H}=0.0119$ (dotted line). This set of results allows us to understand the role of capital regulation for the propagation of shocks. 


\section{Figure 7. Impulse Responses after a Negative TFP Shock (III)}
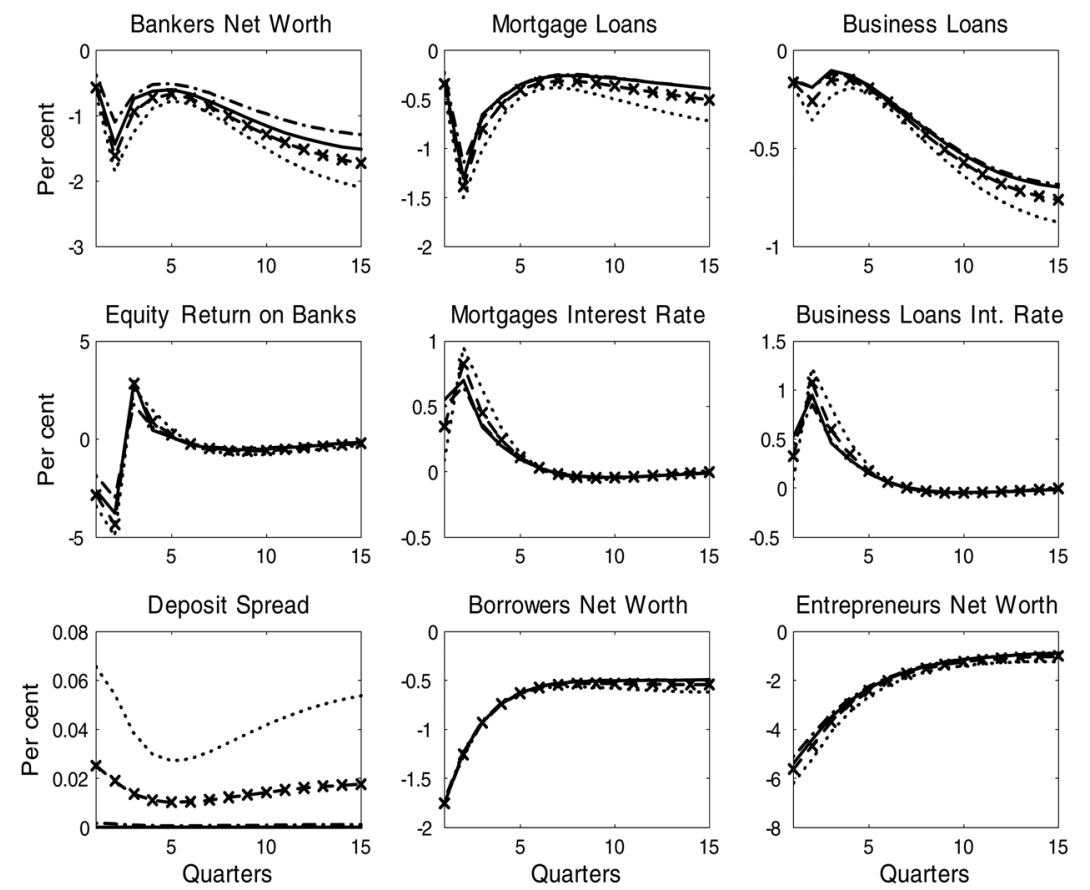

- * - Benchmark $\cdot-\cdot-\cdot$ High Capital Requirement $\cdot \cdots \cdot . \cdot$ High Financial Distress — No Bank Def ault

Notes: "Benchmark" describes the economy with $\phi^{F}=0.08$ and $\phi^{H}=0.04$. "High capital requirement" describes the economy with $\phi^{F}=0.105$ and $\phi^{H}=$ 0.0525. "High financial distress" describes an economy with a variance of the idiosyncratic shock to banks' performance higher than in the baseline parameterization. "No bank default" describes an economy in which the variance of the idiosyncratic shock to bank performance is zero. GDP is defined as net of bankruptcy costs due to default. It is therefore a measure of "net output."

An exogenous reduction in aggregate productivity implies a reduction in spending and production. Thus, the relative price of housing and physical capital decline, leading to an increase in the default by households and entrepreneurs (figure 6). Higher borrowers' default reduces bank capital and, thus, the supply of loans (bank capital channel). At the same time, bank default increases, leading to an increase in the cost of deposit funding, which further increases 


\section{Figure 8. Impulse Responses after a Shock to the Housing and Capital Depreciation (I)}
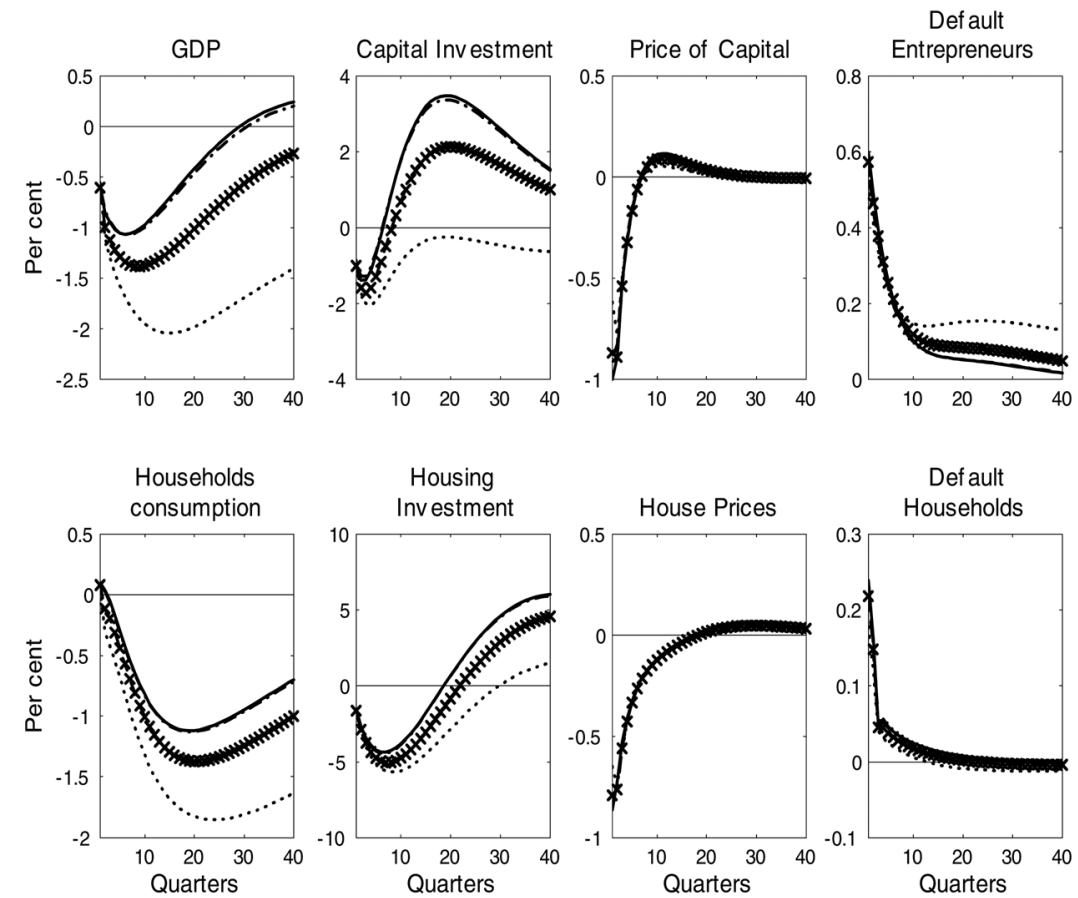

— * - Benchmark $\cdot-\cdot-\cdot$ High Capital Requirement...... High Financial Distress —— No Bank Def ault

Notes: "Benchmark" describes the economy with $\phi^{F}=0.08$ and $\phi^{H}=0.04$. "High capital requirement" describes the economy with $\phi^{F}=0.105$ and $\phi^{H}=$ 0.0525. "High financial distress" describes an economy with a variance of the idiosyncratic shock to banks' performance higher than in the baseline parameterization. "No bank default" describes an economy in which the variance of the idiosyncratic shock to bank performance is zero. GDP is defined as net of bankruptcy costs due to default. It is therefore a measure of "net output."

the bank lending rates that banks have to charge in order to satisfy bankers' participation constraints (bank funding channel). Both channels further contribute to the reduction in the price of houses and physical capital, leading to higher default rates among borrowers (figure 7).

Figures 8 and 9 replicate the same analysis for a persistent negative depreciation shock, namely a negative shock to the value of the 


\section{Figure 9. Impulse Responses after a Shock to the Housing and Capital Depreciation (II)}
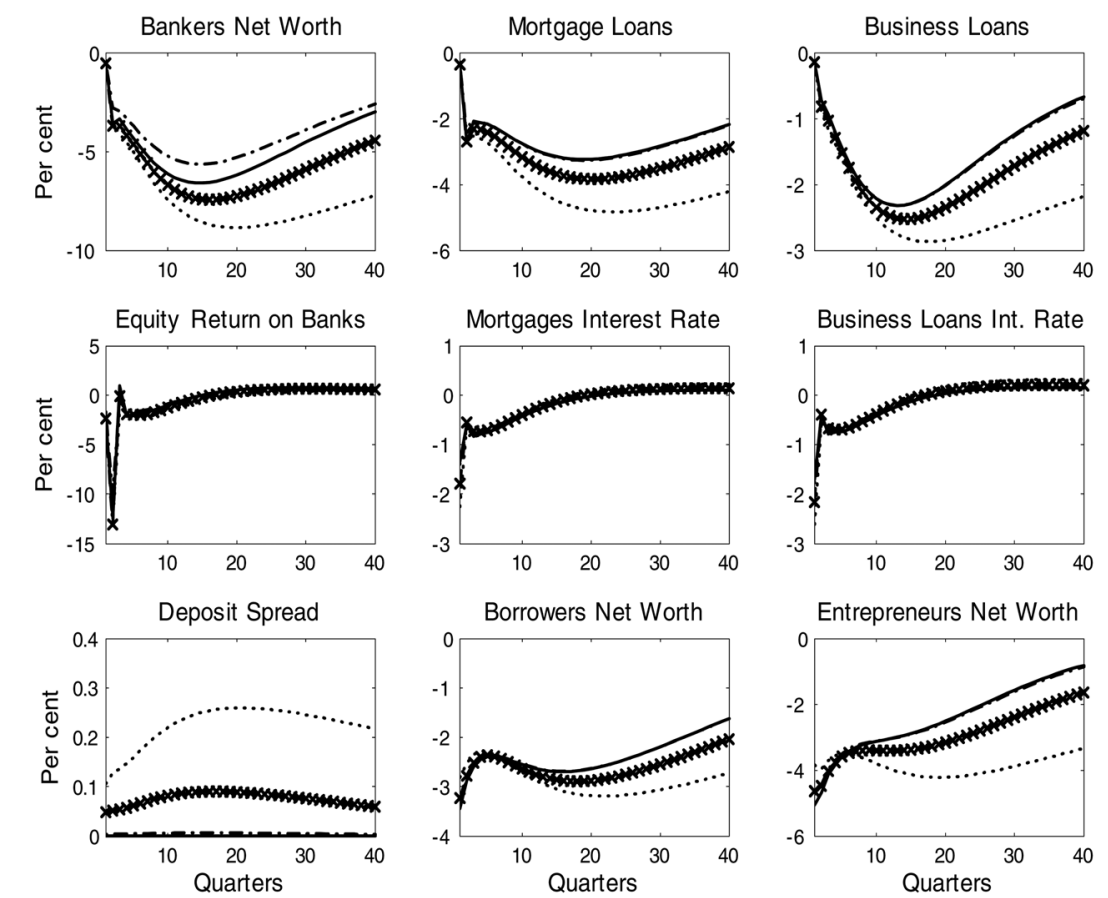

- * - Benchmark $\cdot-\cdot-\cdot$ High Capital Requirement $\cdot . \cdot . \cdot$. High Financial Distress — No Bank Def ault

Notes: "Benchmark" describes the economy with $\phi^{F}=0.08$ and $\phi^{H}=0.04$. "High capital requirement" describes the economy with $\phi^{F}=0.105$ and $\phi^{H}=$ 0.0525. "High financial distress" describes an economy with a variance of the idiosyncratic shock to banks' performance higher than in the baseline parameterization. "No bank default" describes an economy in which the variance of the idiosyncratic shock to bank performance is zero. GDP is defined as net of bankruptcy costs due to default. It is therefore a measure of "net output."

stocks of housing and physical capital (the shock is assumed to hit both stocks in the same proportion at the same time). Also here, even more so than for TFP shocks, the presence of bank default leads to very strong amplification (especially noticeable in, e.g., the response of GDP). In the model with a high capital requirement or no bank default, we find a mild and short contraction of output, but under high bank risk the implied recession is much deeper and long 
lasting. The difference can be largely explained by the different effect on bank capital and bank defaults. Bank capital declines (figure 8) and this restricts the supply of loans in a very persistent way, especially under the high-bank-risk calibration. In addition, bank defaults increase, leading to a rise in the cost of deposit funding, which further depresses economic activity and amplifies the decline in bank capital. Our model features a powerful interaction between bank capital and the bank cost of funding channels of crisis transmission. The result is a deep and persistent decline in economic activity in the economy with low capital requirements (i.e., the benchmark economy).

Figures 10 and 11 report on the dynamic effects of shocks to the standard deviation of the idiosyncratic shocks to banks' performance, which we interpret as a shock to "bank risk." Similar to the results for the depreciation shock, the effects of the shock are very mild in the economy with high capital requirements or an initially low level of bank risk ("no-bank-risk" economy). In the benchmark economy, a high starting value for bank risk, coupled with low capital requirements, has the opposite effect of greatly amplifying the transmission of the shock. Again, the difference is largely explained by the diverging paths for bankers' net worth and the cost of deposit funding.

Figure 12 provides an overview of the key results. Overall, these results suggest that, first, an economy with "high capital requirements" (set close to the welfare-maximizing ones) behaves very similarly to an economy with no bank default. Thus, high capital requirements insulate the economy from the bank net worth channel and prevent excessive volatility due to banks' excessive lending and excessive failure risk. Additionally, the figures show that when bank leverage is high (because capital requirements are low), the economy is more responsive to shocks. This evidences that limited liability and the deposit insurance subsidies, which allow banks to meet the required rate of return on equity with lower lending rates, constitute a potentially powerful channel of financial amplification and contagion.

\subsection{Countercyclical Capital Adjustments}

Figures 13 and 14 summarize the results of running the same exercises as in prior figures but comparing economies with cyclically 


\section{Figure 10. Impulse Responses after a Shock to Bank Risk (I)}
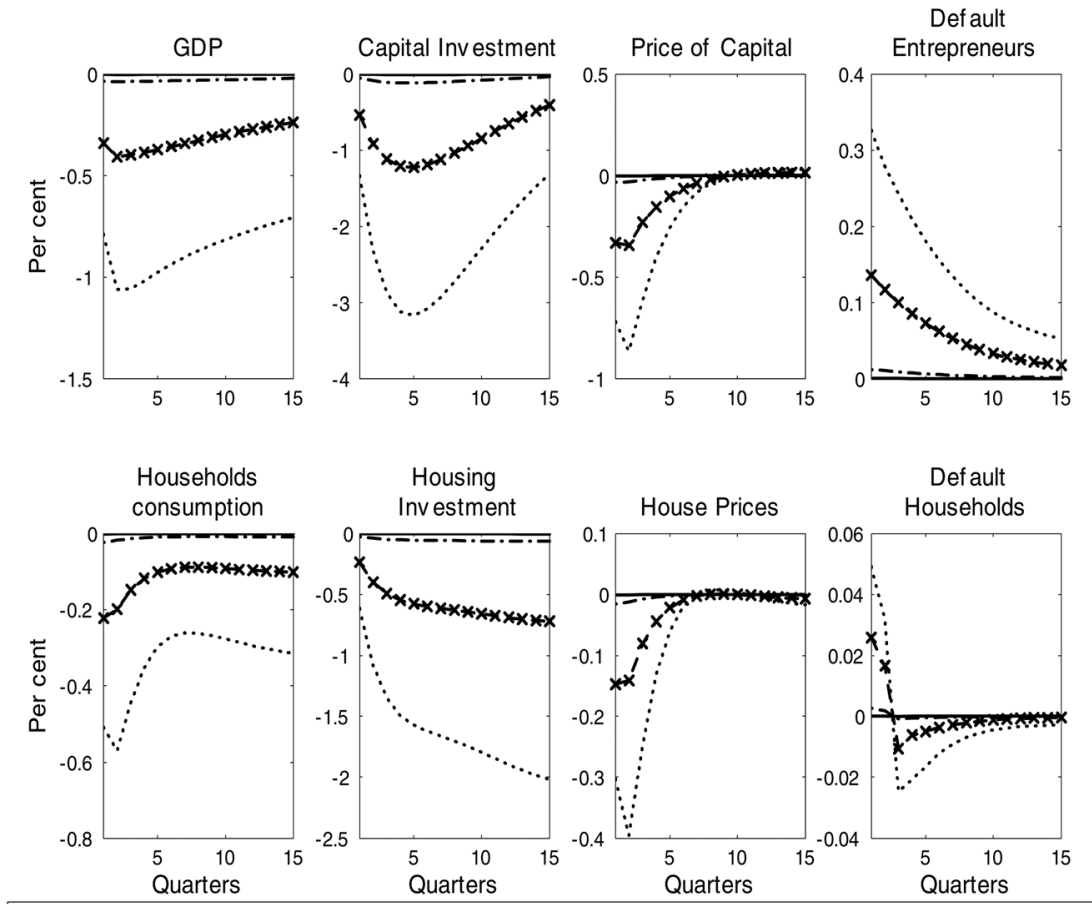

- * - Benchmark $\cdot-\cdot-\cdot$ High Capital Requirement

.. High Financial Distress

- No Bank Default

Notes: "Benchmark" describes the economy with $\phi^{F}=0.08$ and $\phi^{H}=0.04$. "High capital requirement" describes the economy with $\phi^{F}=0.105$ and $\phi^{H}=$ 0.0525. "High financial distress" describes an economy with a variance of the idiosyncratic shock to banks' performance higher than in the baseline parameterization. "No bank default" describes an economy in which the variance of the idiosyncratic shock to bank performance is zero. GDP is defined as net of bankruptcy costs due to default. It is therefore a measure of "net output."

flat capital requirements like in the previous sub-sections with economies in which the capital requirements are cyclically adjusted. In particular, in terms of equation (47), we set $\bar{\phi}_{1}^{j}=0.3$ so that the capital requirements vary according to the percentage deviation of total credit from its steady-state level, in a symmetric fashion. 


\section{Figure 11. Impulse Responses after a Shock to Bank Risk (II)}
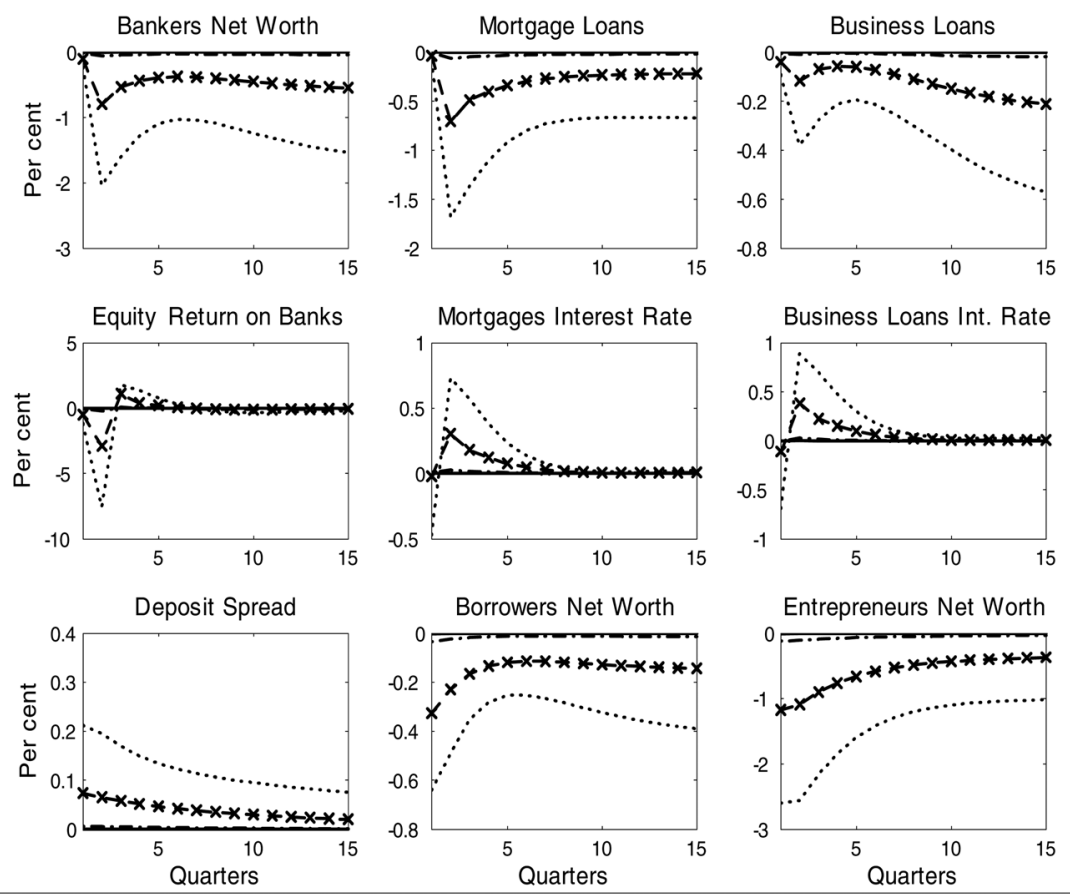

- * - Benchmark $\cdot-\cdot-\cdot$ High Capital Requirement $\cdot \cdots \cdot \cdot \cdot$ High Financial Distress $\longrightarrow$ No Bank Default

Notes: "Benchmark" describes the economy with $\phi^{F}=0.08$ and $\phi^{H}=0.04$. "High capital requirement" describes the economy with $\phi^{F}=0.105$ and $\phi^{H}=$ 0.0525. "High financial distress" describes an economy with a variance of the idiosyncratic shock to banks' performance higher than in the baseline parameterization. "No bank default" describes an economy in which the variance of the idiosyncratic shock to bank performance is zero. GDP is defined as net of bankruptcy costs due to default. It is therefore a measure of "net output."

The results suggest that introducing a countercyclical adjustment mitigates the reduction in the supply of credit to the economy, but does so at the cost of an increase in bank default and, thus, a higher overall cost of funds for banks. It turns out that the countercyclical adjustment adds stability when associated with a high level of capital requirements (i.e., when bank default risk is already very low). 

Figure 12. Overview of Key Impulse Responses after a
Shock to Productivity, Depreciation, and Bank Risk
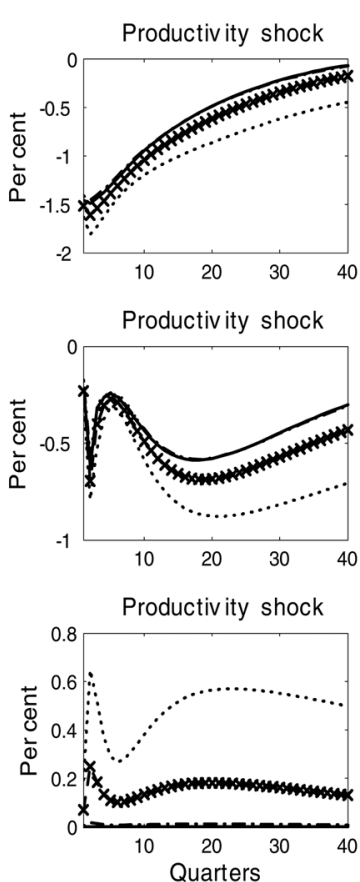

GDP

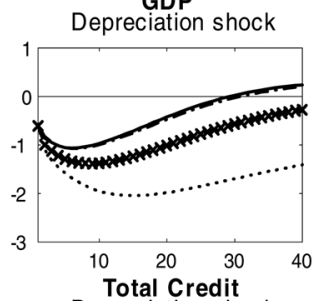

Depreciation shock

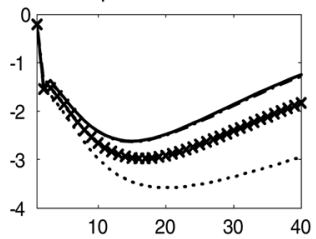

Average Default Banks Depreciation shock

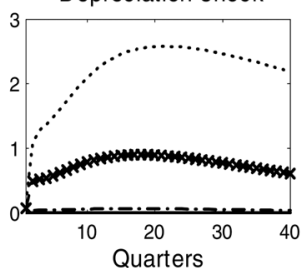

Bank Risk Shock

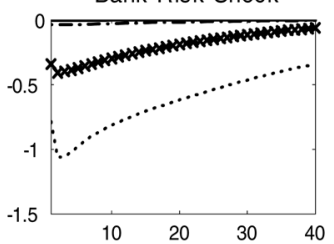

Bank Risk Shock

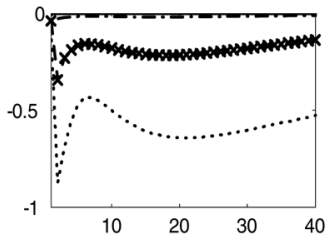

Bank Risk Shock

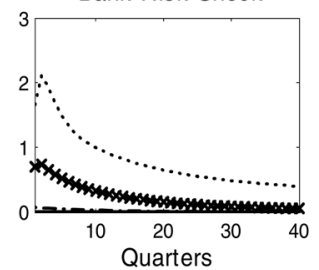

- * Benchmark $\cdot-\cdot \cdot \cdot$ High Capital Requirement...... High Financial Distress—— No Bank Def ault

Notes: A depreciation shock is a shock to the depreciation rates of capital and housing. A bank risk shock is an idiosyncratic shock to each bank's ability to extract payoffs from its loans. "Benchmark" describes the economy with $\phi^{F}=0.08$ and $\phi^{H}=0.04$. "High capital requirement" describes the economy with $\phi^{F}=0.105$ and $\phi^{H}=0.525$. "High financial distress" describes an economy with a variance of the idiosyncratic shock to banks' performance higher than in the baseline parameterization. "No bank default" describes an economy in which the variance of the idiosyncratic shock to bank performance is zero. GDP is defined as net of bankruptcy costs due to default. It is therefore a measure of "net output."

In contrast, when the countercyclical adjustment is added to the economy with low capital requirements, we find that for most shocks and variables the result is more rather than less amplification. The countercyclical adjustment of the capital requirements actually helps moderate the negative output effects of the shocks in the short run. 


\section{Figure 13. Overview of Key Impulse Responses after a Shock to Productivity, Depreciation, and Bank Risk: Benchmark Capital Requirements}
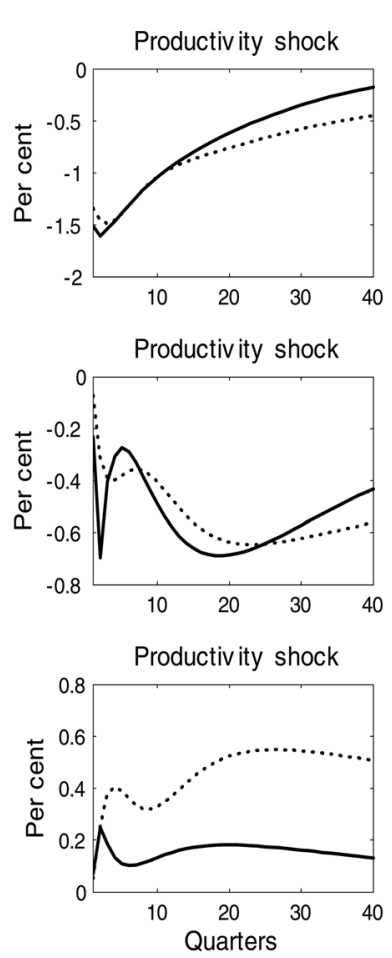
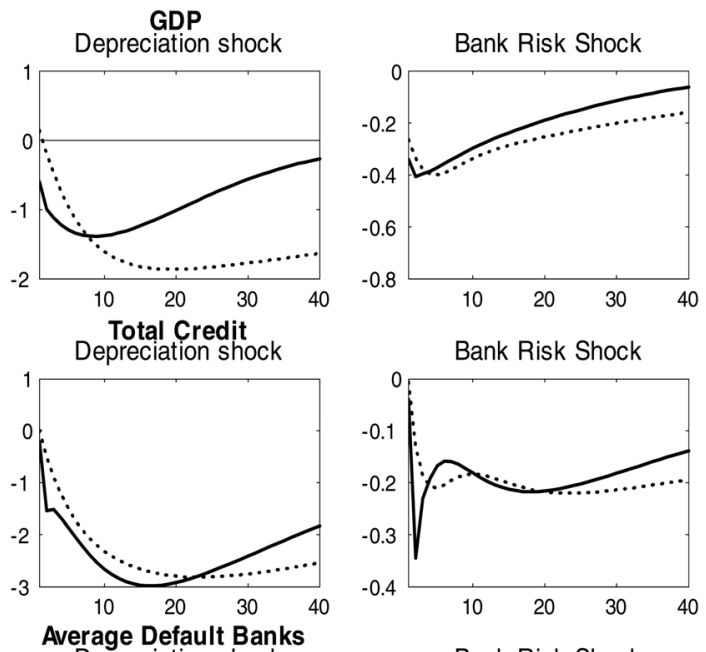

Depreciation shock
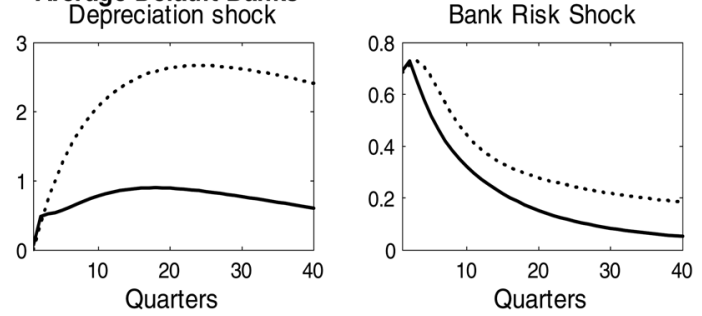

Benchmark $\cdots \cdots \cdot$ Benchmark + CCB(0.3)

Notes: A depreciation shock is a shock to the depreciation rates of capital and housing. A bank risk shock is an idiosyncratic shock to each bank's ability to extract payoffs from its loans. "Benchmark" describes the economy with $\phi^{F}=0.08$ and $\phi^{H}=0.04$. "Benchmark $+\mathrm{CCB}(0.3)$ " describes an economy in which the capital requirement reacts to the percentage deviation of total loans (corporate and mortgage) from their steady-state values, with coefficient of 0.3. GDP is defined as net of bankruptcy costs due to default. It is therefore a measure of "net output."

However, the effects are negative over the medium/long run. Overall, the lesson from this exercise is that relaxing capital standards only works well when the starting capital requirement position is strong. 


\section{Figure 14. Overview of Key Impulse Responses after a Shock to Productivity, Depreciation, and Bank Risk: High Capital Requirements}
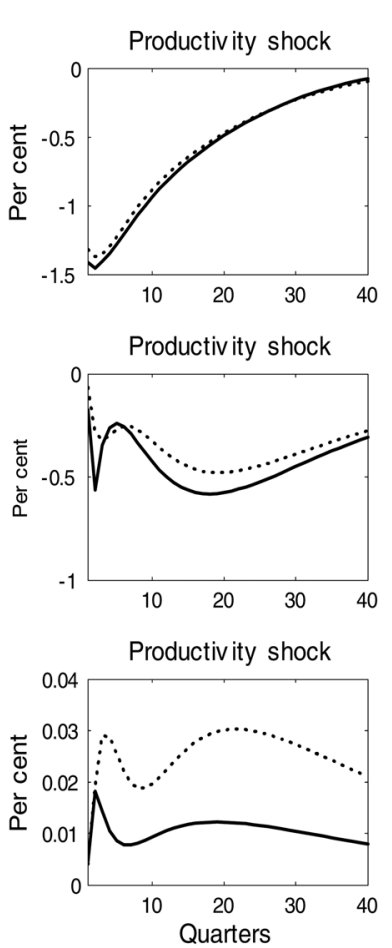

GDP

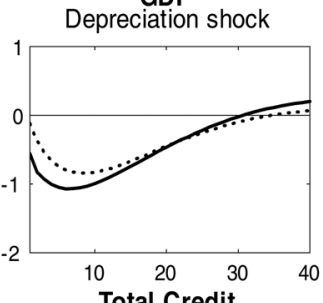

Total Credit

Depreciation shock

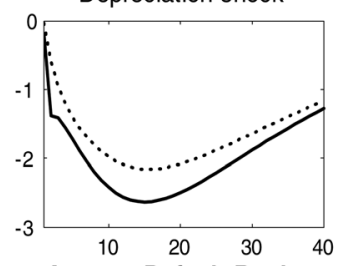

Average Default Banks

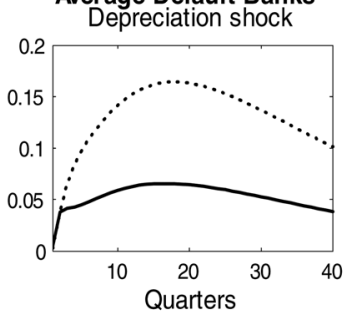

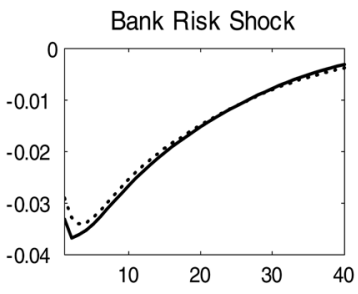

Bank Risk Shock
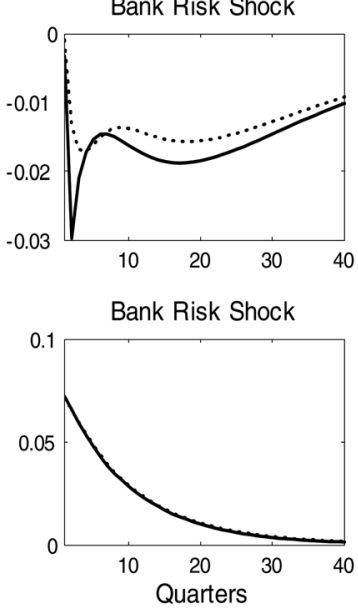

High Capital Requirement $\cdots \cdots \cdots$ High Capital Requirement + CCB (0.3)

Notes: A depreciation shock is a shock to the depreciation rates of capital and housing. A bank risk shock is an idiosyncratic shock to each bank's ability to extract payoffs from its loans. "High capital requirement" describes the economy with $\phi^{F}=0.105$ and $\phi^{H}=0.0525$. "High capital requirement $+\operatorname{CCB}(0.3)$ " describes an economy in which the capital requirement reacts to the percentage deviation of total loans (corporate and mortgage) from their steady-state values, with coefficient of 0.3. GDP is defined as net of bankruptcy costs due to default. It is therefore a measure of "net output."

\section{Conclusions}

In this paper we have proposed a DSGE model with multiple financial frictions affecting households, entrepreneurs, and banks. One distinctive feature of our model is that it contains three layers of 
default and that, unlike most models in previous literature, default has material consequences for the banks' balance sheets. The model allows us to study the macroeconomic consequences of default: the impact of idiosyncratic and aggregate shocks on household and corporate defaults, the effect of loan defaults on bank performance (bankers' net worth, bank failure probabilities), and the feedback effects coming from the importance of these bank variables for the availability and cost of bank credit.

We have focused the policy analysis on bank capital requirements. In our model, bank capital regulation tackles several distortions that may push credit provision away from the first-best solution (the solution that a social planner would select). On the one hand, banks have limited liability, bank deposits enjoy government guarantees, and the pricing of deposits does not fully reflect the risk of failure of each individual bank, which encourages banks to expand their own leverage and potentially become excessively fragile and extend excessive credit to the real economy. On the other hand, costly state verification makes external financing costly, borrowers' investment capacity is limited by their net worth, and this reduces credit compared with the socially optimal level in an ideal economy without these costs. Bank capital regulation needs to find a compromise between reducing the distortions associated with bank failure risk and ending up constraining credit supply excessively. In our baseline calibration, we find that a reasonable compromise can be found at levels of the capital ratio around 10.5 percent, which is above the Basel III levels of capital but below more radical proposals such as those of Admati and Hellwig (2013).

In terms of the dynamics of the model, we find that shock propagation and amplification are large when idiosyncratic bank risk is high and the bank capital requirements are low. Our impulse response analysis indicates that the welfare-maximizing capital requirements largely eliminate the additional amplification otherwise coming from banks' financial vulnerability (bank defaults and fluctuation in bankers' net worth). Finally, our analysis of the effects of making capital requirements countercyclical reveals an interesting non-monotonicity: it is moderately stabilizing when the steady-state level of the requirements is sufficiently high but quite destabilizing when the steady-state level of the requirements is low. 
Importantly, the current parameterization and analysis constitute only a first exploration of the quantitative properties of our model, so the results reported above should be taken with caution. First, the model could be properly calibrated and the analysis could be improved by dealing with non-linearities and stochastic welfare. Then, there are aspects of the construction that might be improved or generalized by relaxing some of the simplifying assumptions of the current setup (such as banks' inability to raise outside equity or the features that make bank capital requirements binding at all times). Additionally, the model could be extended to introduce liquidity risk (and its regulation) and to allow for securitization (and its regulation). Finally, our model is entirely real and considers no nominal rigidities and, hence, has no room for (conventional) monetary policy. However, it would be relatively straightforward to add nominal rigidities in order to study the interplay between macroprudential policy (capital regulation) and monetary policy. Several of these extensions appear to be interesting avenues for future research.

\section{References}

Admati, A., and M. Hellwig. 2013. The Bankers' New Clothes. Princeton, NJ: Princeton University Press.

Aghion, P., and P. Bolton. 1997. "A Theory of Trickle-Down Growth and Development." Review of Economic Studies 64 (2): 151-72. Andreoni, J. 1989. "Giving with Impure Altruism: Applications to Charity and Ricardian Equivalence." Journal of Political Economy 97 (6): 1447-58.

Angeloni, I., and E. Faia. 2013. "Capital Regulation and Monetary Policy with Fragile Banks." Journal of Monetary Economics 60 (3): 311-24.

Bank for International Settlements. 2010. "An Assessment of the Long-term Economic Impact of Stronger Capital and Liquidity Requirements." Basel Committee on Banking Supervision (August).

Benes, J., and M. Kumhof. 2011. "Risky Bank Lending and Optimal Capital Adequacy Regulation." IMF Working Paper No. 11/130.

Benigno, G., H. Chen, C. Otrok, and E. Young. 2013. "Financial Crises and Macro-Prudential Policies." Journal of International Economics 89 (2): 453-70. 
Bernanke, B., M. Gertler, and S. Gilchrist. 1999. "The Financial Accelerator in a Quantitative Business Cycle Framework." In Handbook of Macroeconomics, Vol. 1 Part C, ed. J. B. Taylor and M. Woodford, 1341-93. Elsevier.

Bhattacharya, S., A. Boot, and A. Thakor. 1998. "The Economics of Bank Regulation." Journal of Money, Credit and Banking 30 (4): 745-70.

Bianchi, J. 2011. "Overborrowing and Systemic Externalities in the Business Cycle." American Economic Review 101 (7): 3400-26.

Bianchi, J., and E. Mendoza. 2010. "Overborrowing, Financial Crises and Macro-Prudential Taxes." NBER Working Paper No. 16091.

Brown, M., B. Guin, and S. Morkoetter. 2013. "Switching Costs, Deposit Insurance and Deposit Withdrawals from Distressed Banks." Mimeo.

Brunnermeier, M., T. Eisenbach, and Y. Sannikov. 2012. "Macroeconomics with Financial Frictions: A Survey." Advances in Economics and Econometrics, Tenth World Congress of the Econometric Society, Vol. 2 ed. D. Acemoglu, M. Arellano, and E. Dekel, 4-94. New York: Cambridge University Press.

Brunnermeier, M., and Y. Sannikov. 2014. "A Macroeconomic Model with a Financial Sector." American Economic Review 104 (2): 379-421.

Brzoza-Brzezina, M., M. Kolasa, and K. Makarski. 2013. "The Anatomy of Standard DSGE Models with Financial Frictions." Journal of Economic Dynamics and Control 37 (1): 32-51.

Carlstrom, C., and T. Fuerst. 1997. "Agency Costs, Net Worth, and Business Fluctuations: A Computable General Equilibrium Analysis." American Economic Review 87 (5): 893-910.

Christiano, L., and D. Ikeda. 2013. "Leverage Restrictions in a Business Cycle Model." NBER Working Paper No. 18688.

Christiano, L., R. Motto, and M. Rostagno. 2014. "Risk Shocks." American Economic Review 104 (1): 27-65.

Collard, F., H. Dellas, B. Diba, and O. Loisel. 2012. "Optimal Monetary and Prudential Policies." Working Paper No. 413, Banque de France.

Curdia, L., and M. Woodford. 2008. "Credit Frictions and Optimal Monetary Policy." Working Paper No. 146, National Bank of Belgium. 
Darracq Pariès, M., C. Kok Sørensen, and D. Rodriguez-Palenzuela. 2011. "Macroeconomic Propagation under Different Regulatory Regimes: Evidence from an Estimated DSGE Model for the Euro Area." International Journal of Central Banking 7 (4): 49-113.

Dewatripont, M., and J. Tirole. 1994. The Prudential Regulation of Banks. MIT Press.

Diamond, D. 1984. "Financial Intermediation and Delegated Monitoring." Review of Economic Studies 51 (3): 393-414.

Diamond, D., and P. Dybvig. 1983. "Bank Runs, Deposit Insurance, and Liquidity." Journal of Political Economy 91 (3): 401-19.

Forlati, C., and L. Lambertini. 2011. "Risky Mortgages in a DSGE Model." International Journal of Central Banking 7 (1): 285335.

Gale, D., and M. Hellwig. 1985. "Incentive-Compatible Debt Contracts: The One-Period Problem." Review of Economic Studies $52(4)$ : $647-63$.

Geanakoplos, J. 2003. "Liquidity, Default, and Crashes: Endogenous Contracts in General Equilibrium." In Advances in Economics and Econometrics: Theory and Applications, Eighth World Congress of the Econometric Society, Vol. 2, ed. M. Dewatripont, L. P. Hansen, and S. J. Turnovsky, 170-205. New York: Cambridge University Press.

. 2011. "What's Missing from Macroeconomics: Endogenous Leverage and Default." In Approaches to Monetary Policy Revisited - Lessons from the Crisis, ed. M. Jarocinski, F. Smets, and C. Thimann. (Proceedings of the Sixth ECB Central Banking Conference, November 18-19, 2010.) European Central Bank.

Gerali, A., S. Neri, L. Sessa, and F. M. Signoretti. 2010. "Credit and Banking in a DSGE Model of the Euro Area." Journal of Money, Credit and Banking 42 (s1): 107-41.

Gersbach, H., and J.-C. Rochet. 2012. "Aggregate Investment Externalities and Macroprudential Regulation." Journal of Money, Credit and Banking 44 (s2): 73-109.

Gertler, M., and P. Karadi. 2011. "A Model of Unconventional Monetary Policy." Journal of Monetary Economics 58 (1): 17-34.

Gertler, M., and N. Kiyotaki. 2010. "Financial Intermediation and Credit Policy in Business Cycle Analysis." In Handbook of Monetary Economics, Vol. 3, ed. B. Friedman and M. Woodford, 547-99 (chapter 11). North-Holland and Elsevier. 
Gertler, M., N. Kiyotaki, and A. Queralto. 2012. "Financial Crises, Bank Risk Exposure and Government Financial Policy." Journal of Monetary Economics 59 (Supplement): S17-S34.

Goodfriend, M., and B. McCallum. 2007. "Banking and Interest Rates in Monetary Policy Analysis: A Quantitative Exploration." Journal of Monetary Economics 54 (5): 1480-1507.

Goodhart, C., A. Kashyap, D. Tsomocos, and A. Vardoulakis. 2012.

"Financial Regulation in General Equilibrium." NBER Working Paper No. 17909.

Goodhart, C., P. Sunirand, and D. Tsomocos. 2006. "A Model to Analyse Financial Fragility." Economic Theory 27 (1): 107-42.

Goodhart, C., D. Tsomocos, and M. Shubik. 2013. "MacroModelling, Default and Money." Special Paper No. 224, Financial Markets Group.

Hirakata, N., N. Sudo, and K. Ueda. 2013. "Capital Injection, Monetary Policy, and Financial Accelerators." International Journal of Central Banking 9 (2): 101-45.

Iacoviello, M. 2005. "House Prices, Borrowing Constraints, and Monetary Policy in the Business Cycle." American Economic Review 95 (3): 739-64.

Jeanne, O., and A. Korinek. 2010. "Managing Credit Booms and Busts: A Pigouvian Taxation Approach." NBER Working Paper No. 16377.

Kareken, J. H., and N. Wallace. 1978. "Deposit Insurance and Bank Regulation: A Partial-Equilibrium Exposition." Journal of Business 51 (3): 413-38.

Kiyotaki, N., and J. Moore. 1997. "Credit Cycles." Journal of Political Economy 105 (2): 211-48.

Krasa, S., and A. Villamil. 1992. "Monitoring the Monitor: An Incentive Structure for a Financial Intermediary." Journal of Economic Theory 57 (1): 197-221.

Martinez-Miera, D., and J. Suarez. 2012. "A Macroeconomic Model of Endogenous Systemic Risk Taking." CEPR Discussion Paper No. 9134.

Meh, C., and K. Moran. 2010. "The Role of Bank Capital in the Propagation of Shocks." Journal of Economic Dynamics and Control 34 (3): 555-76.

Miles, D., J. Yang, and G. Marcheggiano. 2013. "Optimal Bank Capital." Economic Journal 123 (567): 1-37. 
Repullo, R., and J. Suarez. 2013. "The Procyclical Effects of Bank Capital Regulation." Review of Financial Studies 26 (2): 452-90. Townsend, R. 1979. "Optimal Contracts and Competitive Markets with Costly State Verification." Journal of Economic Theory 21 (2): 265-93.

Van den Heuvel, S. 2008. "The Welfare Cost of Bank Capital Requirements." Journal of Monetary Economics 55 (2): 298-320. Williamson, S. 1987. "Costly Monitoring, Loan Contracts, and Equilibrium Credit Rationing." Quarterly Journal of Economics 102 (1): $135-45$. 